\title{
Geomorphology and Shallow Structure of a Segment of the Atlantic Patagonian
}

\section{Margin}

A. Muñoz ${ }^{\text {a }}$, J. Acosta ${ }^{\text {b, }}$ J. Cristobo ${ }^{\text {c }}$, M. Druet ${ }^{\text {b }}$, E. Uchupi ${ }^{\mathrm{d} *}$, and Atlantis Group**

a) Tragsa-SGP. Valentín Beato, 6, 3p. 28037 Madrid (Spain). Email: amur@tragsa.es

b) Instituto Español de Oceanografía. Corazón de María 8, 28002 Madrid (Spain). Email: juan.acosta@md.ieo.es

c) Instituto Español de Oceanografía. Centro Oceanográfico de Gijón. C/Príncipe de Asturias 70 bis, 3312 Gijón, Asturias (Spain). Email: cristobo@gi.ieo.es

d) Woods Hole Oceanographic Institution. Woods Hole, MA (USA). Email: elazaruchupi@movistar.es

\section{Abstract}

We study an area little known of the Atlantic Patagonian margin from $44^{\circ} 30^{\prime}$ S to $47^{\circ} 40^{\prime}$ S and from $59^{\circ} \mathrm{W}$ to nearly $61^{\circ} \mathrm{W}$. The multi-beam bathymetry coupled with high resolution seismic reflection profiles, have provided details on the morphology and shallow acoustic structure on this area.

The main morphological characteristics of the seafloor features on the shelf and middle slope are described. The Atlantic Patagonian continental shelf north of $45^{\circ} 40^{\prime} \mathrm{S}$ is located at a depth of $170-200 \mathrm{~m}$ depths, south of this latitude the shelf edge is at 128 to $200 \mathrm{~m}$. The shelf surface is marred by circular depression and ridges oriented oblique to the shelf edge. The upper slope and upper middle slope are plowing by icebergs from Antarctica in Pleistocene and local reefs of cold-water coral further enhance the topography of the area. In the middle slope there are two terraces, the 20 to $60 \mathrm{~km}$ wide Nágera and the 15 to $60 \mathrm{~km}$ wide Perito Moreno terraces, showing moats, hollows, pot holes, sediment drifts and sediment waves. The terraces may have been formed in Late Miocene whereas the other forms are of Pleistocene age. Other features are a sediment swell south of $47^{\circ} \mathrm{S}$ and seven submarine canyons on the middle slope. These incipient canyons have been developed in the middle slope by retrogressive erosion, some terminating on the upper middle slope, and others on the upper slope and the canyon 6 breaching the shelf edge. 
Individual seafloor features existing on the Atlantic Patagonian Margin have been classified into two main groups according to their origin: along and across-slope processes. These primary agents were supplemented by endogenic processes such as expulsion of gas/water, diapirism of high-pressure mud and folding/faulting. The results suggest that today down-slope processes on the slope are practically non-existent and that the morphology of the upper and middle slope is slowly being remoulded by along-slope bottom currents.

Keywords: sediment drifts, submarine canyons, Falkland/Malvinas Current, pockmarks, mud diapirs, deep-water corals.

* Corresponding Author: Corresponding Address: C/ Valentín Beato, 6, 3 planta, 28037 Madrid, Spain. E-mail: amur@tragsa.es. Phone:+34 917822620; Fax:+34 913226335

**Atlantis Group: S. Iglesias, J. Portela, J.L del Río, S. Parra, M. Sacau, R. Vilela, T. Patrocinio, P. Ríos, B. Almón, E. Elvira, P. Jiménez, A. Fontán, C. Alcalá and V. López.

\section{Introduction}

The activity of the Spanish bottom trawl fleet in the SW Atlantic takes place in two different areas, alternating in accordance with the fleet's commercial strategy: within the waters around the Falkland (Malvinas) islands under the management of the Falkland Islands Fisheries Department (FIFD) and on the High Seas (HS). On the HS, its activity is reduced to those portions of the continental shelf and slope not included in the Argentinean EEZ. In accordance with United Nations and FAO recommendations, the Spanish government commenced a series of multidisciplinary research cruises aimed at the study of the Vulnerable Marine Ecosystems (VMEs) and their potential interactions with fishing activities. Within the framework of a VMEs investigation, the R/V Miguel Oliver of the Spanish Secretariat General of Fisheries (SGP) carried out seven cruises in 2007 and 2008 in the southwest South Atlantic. During these cruises, lasting 179 days, the R/V Miguel Oliver mapped 33,984 $\mathrm{km}^{2}$ of the seafloor off 
Patagonia from $44^{\circ} 40^{\prime} \mathrm{S}$ to $47^{\circ} 51^{\prime} \mathrm{S}$ and $58^{\circ} 52$ to $61^{\circ} 05^{\prime} \mathrm{W}$ (Fig. 1). The main objective of the investigation was to locate and map possible VMEs between the Argentine EEZ outer limit and the $1500 \mathrm{~m}$ isobath. The investigation was a multidisciplinary one involving geology-geophysics, biology (benthic and pelagic), ecology and physical oceanography. The main goal of this paper is the morphologic characterization of the study area as well as their shallow acoustic stratigraphy to identify the major sedimentary processes and their changes through time. This knowledge in turn made it possible to define the geologic processes and their potential implications on the distribution VMEs in the Atlantic Patagonian margin.

\section{Methods}

Information regarding the morphology of the Patagonian margin was obtained with a Simrad EM-302 (30 kHz) multi-beam system with a nominal frequency of $30 \mathrm{kHz}$ and an angular coverage of up to 150 degrees and 432 soundings per ping. The achievable swath width on a flat bottom will normally be up to 5.5 times the water depth. The shallow structure of the margin was mapped with a hull mounted Topas PS 18 high-resolution parametric sub-bottom profiler system, with integrated transmitter and receivers. The coverage of these seismic data is shown in (Fig. 2A). Navigation during the survey was via a differential GPS Simrad GN33 using satellite corrections from a Fugro system integrated in a MDM 400 software package with an inertial integrated aided Seapath 200 System.

In addition, a total of 1451 bottom photographs were acquired at 13 stations on the continental shelf and slope with a reflex digital camera of >12 Mpixel, model Nikon D700. Based on the distance between two red laser points reflected on the seafloor individual photographs covered an area of 2 by $1.5 \mathrm{~m}$. Samples of the benthic fauna were obtained with a rock dredge (58 stations) and with a bottom trawl net during fishing operations. A total of 156 bottom samples for sedimentological studies were collected with a megabox corer dredge and an additional 105 samples with a Lofoten sampler (Proyecto 
ATLANTIS, 2009). As no cores were collected during this investigation inferences regarding the origin of the morphologies displayed by the multi-beam maps and 3D diagrams created from them is based solely on their morphologies, seismic profiles and published sources. In the present study we use multibeam bathymetry data, $3 \mathrm{D}$ diagrams created from them, high-resolution seismic profiles, bottom photographs and bottom samples acquire during the investigation for an overall view of the recent geologic history of the Patagonian Atlantic margin.

\section{Geologic Setting}

Multi channel seismic profiles studies by Hinz et al. (1999) and Franke et al. (2007) indicate that a thick sequence of post-rift or drift undisturbed Cretaceous and Tertiary sediments rest on the Early Cretaceous break-up unconformity. The upper part of this sequence consists of bottom current controlled facies. The depositional history of these mounded drifts and their numerous unconformities, were controlled by the expansion-reduction of East Antarctic ice sheet. Hernández-Molina et al. (2010) inferred that the preLate Pleistocene evolution of the Patagonian margin and adjacent deep-sea was as follows: 1.Opening of the Drake Passage about 32-31 Ma (Late Eocene-Early Oligocene) and the onset of the circulation of Antarctic bottom waters that we infer led to the erosion not only of the middle continental slope, but some distance westward of the present shelf break. At that time the slope was much shallower than today and consequently erosion may have been quite extensive. 2. Partial collapse of the Antarctic Circumpolar Current as a result of the constriction of the northern limit of the Drake Passage between 29 Ma and 21 Ma (Lagabrielle et al., 2009). 3. Early middle Miocene, 15 Ma ago, when the Drake Passage was re-opened and a massive aggradational phase took place on the shelf and slope as a result of major subsidence and a marked rise in sea level. This led to the burial of the Late Eocene-Early Oligocene erosional surface. 4. Exhumation of the Late Eocene-Early Oligocene surface in Late Miocene/Early Pliocene in the middle slope as result of enhancement in the intermediate water 
circulation and the formation of the upper slope and the Nágera, Perito Moreno and Piedra Buena terraces on the middle and lower slope.

Piston cores and shallow penetrating seismic reflection data (Ewing and Lonardi 1971; Burckle and Hays, 1974; Hanna et al., 1976) indicate that Eocene sediments crop out between $36^{\circ} \mathrm{S}$ and $48^{\circ} \mathrm{S}$ at a depth of 900 to $2500 \mathrm{~m}$ in the Patagonian margin slope. Burckle and Hays (1974) and Hanna et al. (1976) further stated that the benthic diatoms in the Eocene lutite indicate that these sediments were deposited in waters less than 200 m deep. These observations led Burckle and Hays (1974) to infer that shallow water conditions in the Patagonian middle slope lasted from the Cretaceous to Late Eocene when the middle slope began to subside reaching its present depth by the Miocene. According to Burckle and Hays (1974) exposure of the Eocene strata is due to Miocene erosion. These studies suggest that erosion on the middle and lower slope was so extensive as to exhume the Eocene strata (Perito Moreno and Piedra Buena terraces). Erosion on the upper middle slope (Nágera Terrace) and upper slope, where multi-channel suggest that Oligocene-Pliocene sediments resting on the Eocene are preserved (Hinz et al., 1999; their Fig. 6), was much less.

Piston cores from Maurice Ewing Bank at the eastern end of the Falkland/Malvinas Plateau (49³0’S$51^{\circ} 30^{\prime} \mathrm{S} ; 47^{\circ} \mathrm{W}-40^{\circ} \mathrm{W}$ ) and from the Argentine Basin have added additional information on the changes on the intensity of the Antarctic Circumpolar Current since the Miocene. Variation of the intensification of the Antarcic Circumpolar Current over the Maurice Ewing Bank is marked by erosion in Late Miocene, deposition in Early Pliocene followed by limited deposition and/or no deposition, wide spread deposition followed by a period of limited deposition in Late Pliocene and erosion in Late Pleistocene when Patagonian glaciation was at its maximum (Cieselski et al., 1982). The last phase was followed by the deposition of ice rafted clasts in Late Pleistocene and intermitent deposition from the end of the Pleistocene to the present. Groot et al. (1965) reported that Antarctic (glacial) and subantarctic (intereglacial) diatoms in cores in the Argentine Basin, in the path of the Falkland/Malvinas Current, decreased in depth in the cores. They pointed out that this may suggest that the Flakland/Malvinas 
Current was less vigorous during Early and Middle Pleistocene. All these events probably are recorded in the Patagonian middle slope.

\section{Oceanographic Setting}

As described by Matano et al. (2010) the 320 to 500 km wide Patagonian shelf (Fig. 1) is a region of strong westerly winds, high amplitude tides and large low salinity riverine water discharges. The continental shelf circulation is composed of: (1) a broad superficial layer composed of northeastward flow of cold water that intensifies toward the shelf edge and merges with the northeast flowing Falkand/Malvinas Current; (2) a bottom layer that flows toward the southwest. Deposition on the continental slope is influenced by the northeasterly flowing $100 \mathrm{~km}$ wide Falkland/Malvinas Current that impinges on the upper slope. Piola and Matano (2001) state that the current extends from the sea surface to the ocean floor and that its flow is strongly controlled by the bottom topography. Within the current, at depths shallower than $1000 \mathrm{~m}$, is the northeast flowing Antarctic Intermediate Water (AAIW) and from a depth of $1000 \mathrm{~m}$ to 2000/2200 m is the northeast flowing Upper Circumpolar Deep Water (UCDW). Sedimentation at depths from 2000/2200 m to 3800 m is influenced by the northeasterly flowing Lower Circumpolar Deep Water (LCDW) and at depths of $>3.5>5.0 \mathrm{~km}$ by the north flowing Antarctic Bottom Water (AABW) (Flood and Shor, 1988; Hernández-Molina et al., 2009, 2010). In our area of investigation only the Falkland/Malvinas Current and associated water masses (AAIW and UCDW) have played and are playing a major role in the creation of the morphology of the Patagonian continental slope.

A chlorophyll maximum, that follows the western edge of the Falkland/Malvinas Current along the $200 \mathrm{~m}$ isobath, has been inferred by Matano and Palma (2008) to be the result of intrusions of the upper Falkland/Malvinas Current onto the shelf. These intrusions generate a shelf edge 
pressure gradient and a secondary-cross shelf divergence cell that in turn lead to upwelling along the shelf edge. Matano et al. (2010) pointed out that upwelling formed in this manner impact as far as the inner shelf. The regions of largest cross-shelf exchanges occur south $46^{\circ} 50^{\prime}$ 'S where the upper continental slope is low. This verifies Matano et al. (2010) speculation that the mechanism that drives the intrusions of the Falkland/Malvinas Current onto the shelf may be due to topographic steering of the current. These ocean currents on the Patagonian continental shelf and slope is supported by the occurrence of $\mathrm{N}-\mathrm{S}$ trending, $4.7 \mathrm{~m}$ high, $2.7 \mathrm{~km}$ apart sand ridges on the inner continental shelf at depths of about 10 to 15 m (Parker et al., 1982) and ripple marks documented by Lonardi and Ewing (1971) at a depth of 1409 m.

\section{Results}

The area of the Patagonian margin described in this paper extends from $44^{\circ} 40^{\prime} \mathrm{S}$ to $47^{\circ} 51^{\prime} \mathrm{S}$ and from a depth of $128 / 200 \mathrm{~m}$ on the shelf to more than $1500 \mathrm{~m}$ on the middle continental slope (Fig. 2B). Below we describe the morphology of the features in this area.

\subsection{Geomorphology}

\subsubsection{Outer Shelf}

Only the $30-90 \mathrm{~km}$ wide outer edge of the $360-530 \mathrm{~km}$ wide $\left(44^{\circ} \mathrm{S}\right.$ to $\left.48^{\circ} \mathrm{S}\right)$ Atlantic Patagonian continental shelf was surveyed during the investigation (Figs. 1 and 2B). North of $45^{\circ} 40^{\text {'S }}$ the shelf edge is located at a depth of 170-200 m depths, deeper than the 130-150 m depth reported by Parker et al. (1996). South of this latitude the shelf edge is at 128 to $200 \mathrm{~m}$. The shelf surface is marred by circular depression with diameters of tens of meters and $<5 \mathrm{~m}$ to up to $15 \mathrm{~m}$ high ridges oriented oblique to the shelf edge (Fig. 3) . The cores recovered by Fray and Ewing (1963) 
indicate they consist of pebbles, sand and shell fragments. The ridges are oriented oblique to the shelf edge and are separated by 3 to $4 \mathrm{~km}$ wide troughs opened to the southwest. They probably extend as far west as $64^{\circ} \mathrm{W}$, as bottom notations on Chart 23010 of the Defense Mapping Agency of the United States of America indicate that shelf west of this longitude is blanketed by mud. Topas PS 18 High Resolution Parametric profile (Fig. 4A) indicates that the ridges rest unconformable on a gently undulating surface at a depth of 180-187 m below sea level (assuming a velocity of $1500 \mathrm{~m} / \mathrm{sec}$ ).

An unusual depression mapped during the present investigation was found on the shelf at a depth of 150 $\mathrm{m}$. The depression is $1.1 \mathrm{~km}$ wide and is filled with sediments that dip inward and are about $30 \mathrm{~km}$ thick (Fig. 4B). These strata are exposed on the northeast side of the pockmark. The top of this fill is about 10 $\mathrm{m}$ below the edge of the pockmark. The sediments filling the pockmark are intruded by a diapir with a diameter of $200 \mathrm{~m}$; a height of about $150 \mathrm{~m}$ with its crest about $25 \mathrm{~m}$ below the floor of the pockmark. Rising from the apex of the diapir is $200 \mathrm{~m}$ wide acoustically transparent column that extends to the seafloor. Its top is irregular and convex upward.

\subsubsection{Continental Slope}

The 6 to $20 \mathrm{~km}$ wide upper slope, with a gradient that generally exceeds $2^{\circ}$, descends from the shelf edge at a depth of 128/200 m to a depth of 400-750 m (Fig. 2B). A terrace, the Ewing Terrace (Hernández-Molina et al., 2009, 2010) links two tributaries of Canyon 6 at the base of the upper slope (Fig. 2B). From $36^{\circ} 40^{\prime}$ S to the southern end of the survey area the upper slope is bordered at its base by another terrace (Fig. 2). It is $9 \mathrm{~km}$ wide with its western side at a depth of $250 \mathrm{~m}$ and $350 \mathrm{~m}$ at its eastern edge. The upper slope micro-topography (features having reliefs of $<10 \mathrm{~m}$ ) are oriented parallel to sub-parallel to the trend of the slope (Fig. 3). It consists of circular depressions scattered through its surface, some which form chains and others have 
merged to form narrow grooves and striations parallel to the trend of the slope. North of $45^{\circ} 45^{\prime} \mathrm{S}$ the lower part of the upper slope is hummocky and north of $45^{\circ} 40^{\prime} \mathrm{S}$ its base is entrenched by submarine canyons (Figs. 2B and 3). South of $45^{\circ} \mathrm{S}$, the multi-beam bathymetry show $0.3-32 \mathrm{~km}$ long, 73 to $685 \mathrm{~m}$ wide and 10-25 m deep grooves cut the upper slope, they trend northeast. From their similarity to known iceberg plow marks López-Martínez et al. (2011) inferred that icebergs from Antarctica cut them in the Late Pleistocene.

The 67 to $100 \mathrm{~km}$ wide middle continental slope ranges in depth from 400-750 $\mathrm{m}$ on its inner to $1400 \mathrm{~m}$ at its outer edge. Its overall gradient ranges from $1.20^{\circ}$ between the canyons at the northern end of Fig. $2 \mathrm{~B}$ to $0.5^{\circ}$ to $0.35^{\circ}$ at its southern end. The increase in the declivity of the middle slope from $1.35^{\circ}$ to $2.50^{\circ}$ at $59^{\circ} \mathrm{W}$ suggests that the transition from the middle to the lower slope takes place at, or near, a depth of $1400 \mathrm{~m}$.

Morphologies on the upper middle slope include the four steps A-D imaged by Fig. 5. Step A may represent a slump block, or a high eroded out of the middle slope sediments, and V-shaped notches on step B may represent iceberg plow marks. Step C consists of two flat-top highs separated by a low with a small high in its middle. Step D has a gently undulating top underlained by two sequences separated by unconformities; both the units and the unconformities separating them extend beneath Step C. Reflectors between the two unconformities are broadly undulating with the strata beneath the lower unconformity being planar.

Seven canyons cut the slope with four of them (southern branch of Canyon 3 and canyons 2, 1 and 0 ) having their heads in the area of the grooves. Canyon 6 at the northern end of the middle slope extends onto the outer shelf and in plan view looks like a typical canyon with its many tributaries. Three canyons, (5 and 4 and the northern branch of Canyon 3), cut into the lower part of the upper slope and four (the southern branches of Canyon 3 and canyons 2, 1 and 0), terminate on the upper middle slope. Cutting the middle slope also are gullies on either side of Canyon 5 (Fig. 2B and 6). 
The most unusual of the canyons is canyon 3 with its numerous branches in the middle slope. The courses of the canyons display sections that are straight and broadly meandering with local sharp bends around topographic highs including a cluster of mounds displaying tens of meters of relief along the rims of Canyon 2. Canyon 4 is bordered on the north side by a sediment rise that pinches to the west and widens to $35 \mathrm{~km}$ at the eastern end of the study area. It has a relief of about 50 and its rounded top is covered by sediment drift.

A remarkable feature is the $60 \mathrm{~km}$ long trunk of Canyon 0, with a single tributary on its south side. Both the canyon and its tributary die out on the upper middle slope (Fig. 2B). It also terminates before reaching the scarp along the west side of the Perito Moreno Terrace. A faint channel may link the canyon to a $10 \mathrm{~km}$ long and $2 \mathrm{~km}$ wide narrow depression cut on this scarp (X, Figs. 2B and 6). The main part of the canyon is surrounded by circular depressions which disrupt its walls given them a scalloped form; along its axis also are a chain of depressions.

The canyons can be traced to the eastern end of our survey area. A map by Lonardi and Ewing (1971, their Fig. 7) indicates that the canyons drain into Almirante Brown Transverse Canyon at a depth of about $3500 \mathrm{~m}$.

The middle slope is made of two terraces that were named the Nágera and Perito Moreno terraces by Hernández-Molina et al. (2009, 2010; Fig. 2B). The Nágera Terrace extends from the base of the upper slope to a depth of 930 to $1060 \mathrm{~m}$ and the Perito Moreno Terrace from a depth of about 1100/1200 to $1400 \mathrm{~m}$. Nágera Terrace ranges in width from about $20 \mathrm{~km}$ at its northern end to 80 $\mathrm{km}$ at its southern end between canyons 1 and 0 . Perito Moreno Terrace is more than $50 \mathrm{~km}$ at its northern end and $<20 \mathrm{~km}$ at its southern end. From Canyon 4 to Canyon 6 the terraces are separated by an east facing rise in the seafloor with a relief of about $50 \mathrm{~m}$.

The acoustic stratigraphy farther down the Nágera Terrace is displayed in Fig. 5-C. This WestEast profile extending from the outer edge of the Nágera Terrace to the low south of Canyon 2 shows a sequence with a wavy top at its east end. The profile suggests that this drift has climbed 
up a $75 \mathrm{~m}$ high scarp forming the western boundary of the low south of Canyon 2. Extending westward from this scarp is an $18 \mathrm{~km}$ wide platform, the eastern end of the Nágera Terrace. The four sequences on the platform are truncated by the scarp and onlap westward on an erosional surface dipping eastward. The top of the sequence is convex upward. The main part of the Nágera Terrace farther west is blanketed by three units, a lower one with a wavy top onlapping a surface of probable erosional origin (lower $U$ ), a stratified middle unit onlapping the lower one and a top unit prograding over the two units that has an internal structure consisting of wavy reflectors.

A 150 to $38 \mathrm{~m}$ high scarp with a declivity that ranges from about $18^{\circ}$ to $23^{\circ}$ separates the terraces between canyons 2 and 4 . The crest of the scarp ranges in water depth from 940 to $1060 \mathrm{~m}$ has a relief of $150-200 \mathrm{~m}$. A moat at the base of this scarp is $130 \mathrm{~km}$ long, 0.5 to $17 \mathrm{~km}$ wide and about 1140 to $1210 \mathrm{~m}$ deep. The moat consists of a chain of depressions ranging in shape from lunar, to butterfly, to lenticular to narrow to linear. Topographically the moat can be divided into two sections. From the southern tributary of Canyon 3 to Canyon 2 the west wall of the moat is cut by east-west trending gullies. From Canyon 3 to the southern edge of Canyon 4 the moat is made up of isolated lenticular, butterfly and lunar shaped depressions with reliefs of tens to more than 100 m. Canyon 4 truncates the northernmost of these lows (Fig. 2B).

A seismic reflection profile paralleling the southern rim of Canyon 4 indicates that the N-S trending lunar-shape depressions is steep sided with the side slopes facing each other having declivities of $18^{\circ}$ (Fig. 6 and 7A). The depression is $6 \mathrm{~km}$ wide and $220 \mathrm{~m}$ deep, has a high in its center with its east slope being $38 \mathrm{~m}$ high and its western one $150 \mathrm{~m}$. A core recovered from the site by Ewing and Lonardi (1971; 45 $27.9^{\prime}$ 'S; $59^{\circ} 40.1^{\prime} \mathrm{W} ; 1180 \mathrm{~m}$ depth uncorrected) consisted of Eocene lutite. As this core reached Eocene lutite on a steep rugged wall it probably came from the base of the west wall of the scour as only this scarp reaches a depth close to the one from where the Eocene lutite was cored. In the center of the scour is a mound separating the two wings of the butterfly-shaped scour. The sediments, with their undulating tops, surrounding the high represent a current generated sediment drift. The floor 
of the Nágera Terrace west of the scour displays a broadly undulating surface that appears to be parallel to the scour (Fig. 7A).

Along the seismic reflection profile in Fig. 7B, south of the profile described above, the N-S trending moat has a steep side on its west side with a declivity of $23^{\circ}$ and a high at is base. Along the northeast edge of the moat is another high with a rounded top. A sediment apron disrupted by a depression blankets the Perito Moreno Terrace (P, Fig. 7B). These sediments are a sheet drift resting on an irregular surfaced horizon (U). The irregular reflection may be coeval to horizon $\mathrm{H} 2$ of Ewing and Lonardi (1971), which they inferred, is the top of an Eocene lutite. At the base of the acoustic section southwest of the moat, on the Nágera Terrace, also is a strong reflecting horizon whose topography mimics the two low relief highs having seafloor expression. We infer that these reflectors are BSRs. To the southwest of the highs is a flat-bottomed V-shaped depression with a relief of about $100 \mathrm{~m} \mathrm{(H//P?,} \mathrm{Fig.} \mathrm{7B).} \mathrm{The}$ sediments immediately below it are acoustically transparent. Southwest of this depression is a terrace covered with sediment drifts (Fig. 7B).

South of Canyon 2 the scarp separating the two terraces is cut by a southwesterly to northwesterly low extending as much as $40 \mathrm{~km}$ into the Nágera Terrace. Its southwest edge is cut by gullies extending to the field of iceberg plow marks (Fig. 2B).

Within this low is a NW-SE trending $22 \mathrm{~km}$ long, 5 to $7 \mathrm{~km}$ wide and 350-400 m high ridge (R in Fig. 2B and Fig. 8). The high is made up of three segments, a southeast segment convex southward with a sharp narrow crest; it is separated from the central segment of the ridge by a narrow saddle. The southeast end of this segment is flat-iron in shape (Fig. 8C). A central segment has a triangular cross-section at its southeast end and at its northwest end is a narrow sharp-crested high slightly convex to the north. The crest of the northern segment of the ridge diminishes in relief in direction of Canyon 2 (Fig. 8A, B).

The northern face of the southern segment of the ridge is scarred by rills divided in two by a broad chute that extends from the ridge's crest to its base. Similar chutes also scar the central 
segment. The north face of the northern segment consists of protrusions separated by narrow embayments. An irregular surfaced northeast trending spur dominates the northern tip of the ridge's northern segment. About $20 \mathrm{~km}$ north of the ridge is a low relief high convex to the south (Fig. 8B). South of this low the slope separating the Nágera and Perito Moreno Terraces is about $50 \mathrm{~m}$ high and has a gradient of less than $1^{\circ}$.

Along the eastern edge of the Perito Moreno Terrace at $46^{\circ} 20^{\prime}$ S (Figs. $2 \mathrm{~B}$ and 6 ) is also another scarp that descends to the Piedra Buena Terrace at a depth of 1500-2500 m. This scarp is characterized by a series of steps with the risers having reliefs of tens of meters with the steps being tens of $\mathrm{km}$ in width. Along the risers in some of these steps is a chain of ellipsoidal shaped depressions elongated in a northerly direction.

A 750 to 1100 m deep low occurs between canyons 1 and 2 that trend SW-NE (Fig. 2B). It is $50 \mathrm{~km}$ long, has a maximum width of $10 \mathrm{~km}$ and consists of two W-E trending grooves and an SW-NE trending triangular outlined depression. The depression has an amphi-theater shaped low on its northern edge and finger-like prolongations at its west tip. These prolongations represent gullies that serve as feeders to a scour to the east. The low, which is cut into the scarp separating the Nágera and Perito Moreno terraces, extends some $40 \mathrm{~km}$ into the Nágera Terrace.

Along the scarp separating the Perito Moreno and Piedra Buena Terraces is a series of E-W trending ridges and troughs (Fig. 9-1). These features are 15 to $45 \mathrm{~m}$ wide and 20 to $25 \mathrm{~m}$ deep.

South of $47^{\circ} \mathrm{S}$ a swell, orthogonal to the shelf edge, dominates the middle slope. We have named the top of this swell the South Nágera Terrace. This high is reflected in the bottom contours (Fig. 2B) by the change in their trend from N-S to NW-SE. The swell is bordered to the north by Canyon 0, is flanked on the east by the scarp descending from the Perito Moreno Terrace to the Piedra Buena Terrace and it onlaps the upper middle slope on the west. Its southern boundary is beyond the southern limit of the present survey. Its surface, dips gently eastward with a gradient of $0.18^{\circ}$ to a depth of about $800 \mathrm{~m}$. At that depth the declivity of the seafloor increases to $0.30^{\circ}$ as 
it descends the top of the scarp long the east side of the Perito Moreno Terrace. With the exception of a N-S trending groove at $60^{\circ} \mathrm{W}$ and the iceberg plow marks along its western side the surface of the swell is smooth and lacks the irregular topography of Nágera and Perito Moreno terraces north of Canyon 1.

The stratigraphy of the swell imaged by the east-west trending profile (Fig.10) consists of four units with the upper three upper units resting on reflector (U1) displaying different acoustic impedance along its length. Unit 2 above this unconformity has a hummocky top and its thickness (based on $1500 \mathrm{~m} / \mathrm{sec}$ ) ranges from $67 \mathrm{~m}$ at the western of the profile, $83 \mathrm{~m}$ in its center and $30 \mathrm{~m}$ at its eastern end. Much of the unit is acoustically transparent down dip, but is stratified at its eastern end. These stratified strata are disturbed, probably due to mass wasting, and intruded by acoustic transparent columns (insert, Fig. 10). Resting unconformable on Unit 2 are two sequences, a lower acoustically transparent unit (3) and upper stratified unit (4). These units have prograded over Unit 2 and pinch out down slope on unit 2.

The north-south seismic reflection profiles (Figs. 6 y 11) of the swell display the same acoustic intervals as the profile in Fig. 10. The sequence consists of three units (2-4) resting on a horizon (U), the top of Unit 1 . Resting on this reflector, Unit 2 is partially stratified to acoustically transparent unit and consists of a chain of flat-topped highs separated by V-shaped lows of extensional origin. Atop Unit 2 are a transparent lower one (Unit 3) and a stratified upper one (4) that appears to onlap the lower one. These units display compressional structures down dip.

Along the northern edge of Canyon 4 the sediments mantle a swell with a foundation of probable Tertiary sediments cut by chimneys formed by expulsed gas (Muñoz et al., 2012), a maximum relief of $60 \mathrm{~m}$, a maximum width of $20 \mathrm{~km}$ and length of $58 \mathrm{~km}$. Their topographic and acoustic similarity to known sediment drift has led us to infer that are sediment drifts deposits. Faugères et al. (1999) have described seven types of drifts. Examples of sheet, mounded and plastered drifts, occur on much of the middle slope (Muñoz et al., 2012). 
Seismic reflection profiles indicate that the drift internal geometry ranges from more or less transparent to poorly to well bedded. Most drifts rest on an irregular strong reflecting horizon dipping gently eastward. In places this horizon crops out among the drift. Where exposed, it displays an undulating morphology suggestive of molding by bottom currents. Possibly these sediments are correlative with the Eocene gray lutite cored by Ewing and Lonardi (1971; 47 28.7’ S; 59 20.6’ W; 1164 m, uncorrected) in the general area. The core recovered by Ewing and Lonardi (1971) was from "a generally smooth seafloor with moderate undulations” having reliefs of $\pm 37 \mathrm{~m}( \pm 20 \mathrm{fms})$.

South of Canyon 2 the drift deposits along the east side of the Perito Moreno Terrace are fairly continuous, but north of Canyon 2 the drifts are thin and patchy with the greatest accumulation occurring in topographic lows (SC, Fig. 2B). This deposition on the lows has smoothed out the irregular topography of the outer edge of Perito Moreno Terrace north of Canyon 2 (Fig. 12). The most striking feature displayed by some of these deposits is the acoustically transparent columns of varying widths rising from below the strong reflecting horizon forming the foundation of the drifts (Fig. 9-2). Morphologic features as pockmarks, gas chimneys, acoustic wipeouts, diapirs, folds, faults and possibly carbonate mounds occur in the Atlantic Patagonian slope. Pockmarks appear in concentrations on the Nágera and Perito Moreno terraces from Canyons 1 to south of Canyon 0 near $47^{\circ} \mathrm{S}$. DTM, compiled from the multi-beam data, also show that the circular to ellipsoidal pockmarks are present on the shelf and upper slope (Fig. 3). They occur as isolated depressions, in groups, aligned to form a chain or a train or in association with larger structures (Fig. 13). They generally have reliefs of 10 to $120 \mathrm{~m}$, diameters of $<10$ to $80 \mathrm{~m}$ and display a north-south and east-west trend or a random pattern.

Other features are the vertical structures displayed in Figs. 9-2 and 10, the acoustic wipeouts, the diapir structures and the folds in Fig. 11B and 14.

In Figs. 9-2 and 10 the vents appear to originate below a high impedence reflector at the base of the seismic section. In the seismic sections the chimneys appear to very narrow, but this is a reflection of the profiles vertical exaggeration (40X in Fig. 9-2 and 35X in Fig. 10). Corrected for this exageration the 
column marked C in the insert of Fig. 11 is $200 \mathrm{~m}$ wide and $32 \mathrm{~m}$ high (based on a velocity of 1500 $\mathrm{m} / \mathrm{sec}$ ). Thus, most of the columns imaged in Figs. 9-2 and 10 are probably wide vents with their lateral extent being greater than their heights. Some vents terminate abruptly before reaching the seafloor (Fig. 9-2); others reach the seafloor terminating in a pockmark (Fig. 14).

Some pockmarks (Fig. 14A) are not connected to any column. In the insert in Fig. 9-2 the columns display a dendritic pattern that diverges upward with the branches terminating before reaching the seafloor. The acoustic wipeouts imaged at the northern end of the profile in Fig. 14A are masking the bedding. Such masking probably also is present at the northeast of line 17-1107 (Fig. 15). The high between two moats in Fig. 15 probably has the same stratification as the drift to its southwest, but the presence of free gas has led to created by its chaotic acoustic signature. Such masking by free gas, however, could not be responsible the uplift at the northern end of the profile or the folding noted in much of the profile in Fig. 14A. The compression in Fig. 14A is due to the mobility of Unit 2. It and the other units are correlative with the units in the profiles Figs. 10 and 11 . This vertical mobility of Unit 2 is more evident in Fig.14B where a diapir is clearly imaged in the profile. All the folds and vents, have been eroded and covered by a thin sediment veneer (Unit 5; Fig. 14). This unit may be the surface muddy sands sampled during the investigaton. The top of one of the folds in Fig. 14 is cut by grooves that we infer to represent iceberg plow marks as they occur within a wide expanse of such structures. Another interesting feature is the cluster of carbonate mounds tens of meters high located along the edge of Canyon 2 (Fig. 16). We infer, from their topographic simiarity to carbonate knolls described by Hovland et al. (1994) off Australia, that the mounds were formed from methane-derived authigeniuc carbonates. Similar features have been descibed from both active and passive margins and the geologic record (León et al., 2006; Magalhães et al., 2012). In the Gulf of Cadiz these carbonates comprise of dolomite and aragonite (Magalhães et al., 2012).

Probably the most enigmatic feature we found associated with sediments with free gas are subsurface units with irregular tops (Fig. 17). These units are found on three levels (BH1-BH3) and rest on a 
horizontal high amplitude reflector which may be the top of ice rafted sediments. The deepest structure is at $60 \mathrm{~ms}$ TWTT below the seafloor, the second at 30-40 ms and the third at less than $10 \mathrm{~ms}$. They could be sedimentary in origin or in some way related to the gases migrating upward in the sediments, but acoustically they resemble the siliceous sponges described by Conway et al. (2005) off western Canada.

\section{Discussion}

\subsection{General Statement}

The 3D oblique images created from the multi-beam data in Figs. 18 and 19 and the morpho-facies map in Fig. 20 show that the seascape of the Patagonian middle slope is created by four classes of processes, exogenic: along-slope and down-slope sediment transport, endogenic: expulsion of gas/water, extension and compressional deformation, biogenic: deep-water coral accretion and chemical precipitates. Inferences as to how these forces acted on the seafloor is based on the high resolution low penetration seismic reflection profiles, multi-beam data, bottom photographs and bottom surface spot and dredge samples collected during the cruises aboard the R/V Miguel Oliver. That bottom currents may not be as effective now as they were in the recent past is indicated by the prestine state of preservation of the Late Pleistocene iceberg plow marks on the upper and upper middle slope. Analyses of the surface sediments samples collected during the investigation (Proyecto ATLANTIS, 2009) show that the shelf is covered by sands and the upper and middle slope by muddy sands with the sediments containing a higher organic south of $46^{\circ} 30^{\prime} \mathrm{S}$, the area of the sediment swell. The sands and muds probably reflect two sediment cycles with the muds being more recent; the mixture of the two facies probably is due to bioturbation. Bottom photographs indicate that the upper slope from a depth of 300 to $500 \mathrm{~m}$ (Fig. 21) is covered by cold water corals as is the northwest trending ridge south of 
Canyon 2 (Muñoz et al., 2012). Apparently a combination of topography and oceanography have a provided a suitable habitat for these organisms to fluorish. 3D diagrams construction from the multibeam and seismic profiles also indicate that in places this fauna is associated with pockmarks. The same photographs also indicate that the seafloor at the base of the upper slope is a tranquil environment and that the outer edge of the Perito Moreno Terrace south of Canyon 2 is covered by ripple gravelly sands with the larger clasts, probably iceberg drop stones, serving as foundation for individual cold-water corals.

The presence of the ice rafted sediments on the eastern edge of the Perito Moreno Terrace, the similar sediments recovered by Ewing and Lonardi (1971) farther west, and the presence of iceberg plow marks on the upper and upper middle slope indicate that Late Pleistocene icebergs must have covered much of the waters over Atlantic Patagonian upper/middle continental slope. Such coverage must have had a considerable impact on the oceanography, geology and biology of the area. As indicated by LópezMartínez et al. (2011) the presence of iceberg plow marks as far north as $45^{\circ} \mathrm{S}$ indicate that waters off Patagonia during Late Pleistocene must have been colder than now.

Today the Falkland/Malvinas Current breaks into two branches south of the Falkland/Malvinas Islands, a stronger eastern branch that passes east of the islands and a western weaker branch that passes west of the islands (Arkhipkin et al., 2004). It is the $100 \mathrm{~km}$ wide eastern branch that impinges on the Patagonian upper slope that influences sedimentation on the middle slope. During Late Pleistocene, when sea level was 120 m lower than now the western current was forced eastward strengthening the eastern branch. Such a change in the Falkland/Malvinas Current must have had an impact on the sediment regime of the middle slope. That the intensity of the Falkland/Malvinas Current may have varied during the Pleistocene is supported by the flora in the cores in the Argentine Basin (Groot et al., 1965).

\subsection{Present Investigation}




\subsubsection{Along-Slope Processes}

From the studies described on the section on the geology of the region we speculate that the features on the shelf and slope imaged by our multi-beam and seismic reflection data reflect two events. During Late Miocene the slope experienced extensive degradation by along-slope process resulting in the formation of the Nágera and Perito Moreno terraces and the slopes separating them north of Canyon 0. South of this canyon the presence of sediment swell, whose top forms the South Nágera Terrace, suggest that down-slope processes predominated there at that time. The presence of sediment drifts, moats, hollows, pot holes and submarine canyons and gullies indicate that the surfaces of the terraces north of Canyon 0 and along the eastern edge of the sediment swell were modified by down and alongslope processes which we infer to have taken place in Late Pleistocene. The area south of Canyon 0 continued to be a site of down-slope sedimentation. The presence of these two processes in the Pleistocene, that Lastras et al. (2011) inferred to be contemporary, makes the Patagonian continental slope unique among the Atlantic margins. Gravitational tectonics and the occurrence of thermogenic features such as pockmarks formed by the expulsion gas/water, free gas on the sediment and the occurrence of intrusive and compressive features in the area of Canyon 0 further add to the complexity of the Late Pleistocene history of the Atlantic Patagonian shelf and slope. Features sculptured by along-slope processes occur from the shelf to the eastern limit of our investigation. We infer that the ridges on the Patagonian outer shelf south of $45^{\circ} 30^{\prime}$ S, like those on the inner shelf (Parker et al., 1982), were formed by a northward flowing current with an offshore flow component near the bottom during the last post-glacial transgression. We also speculate that notches on the shelf edge (Fig. 3) may be due to the frictionally driven intrusions of the Falkland/Malvinas Current onto the shelf. 
Along-slope structures on the slope have two origins; plow marks cut by grounded icebergs and current generated structures. The plow marks cut into the upper slope and the upper middle slope (upper Nágera Terrace) were inferred by López-Martínez et al. (2011) to have been cut 20,000 years ago by iceberg that originated in Antarctica. The 1.0 to 0.7 Ma extensive field of ice rafted debris in the Maurice Ewing Bank at the eastern end of the Falkland/Malvinas Plateau (Cieselski et al., (1982) suggests the possibility that the plow marks in the upper/ middle slope may be older than inferred by López-Martínez et al. (2011).

As imaged by Figs. 5, 7, 9, 10, 11, 12, 18 and 19 bottom current generated features are best developed along the eastern edge of the Nágera Terrace, along the slopes separating the Nágera and Perito Moreno terraces and the Perito Moreno and Piedra Buena terraces. As a consequence of differences in the velocity and intensity of the currents and of Coriolis force the features formed by along-slope process display two morphologies. Where currents are very strong erosional forms predominate and where currents are not as intense drifts form. Sheet drifts tend to form under a regime of slower and widely spread currents, whereas mounded drifts tend to be constructed in an environment of higher velocities. Sediment supply controls the size, relief and thickness of the drifts (Faugères and Stow, 2008). In the Patagonia Atlantic margin erosional forms tend to be more abundant along the base of the scarp separating the Nágera and Perito Moreno Terrace, along segments of the scarp separating the Perito Moreno and Piedra Buena Terrace where steps were carved by the currents and in the low south of Canyon 2 where moats and hollows have been carved out of the sediments. Sheet drifts cover the surfaces of the terraces where velocities slower and more spread. Mounded drifts occur along the scarp separating the Perito Moreno and Piedra Buena terrace where its declivity increases as it descends to the Piedra Buena Terrace and in the low south of Canyon 2.

Along the eastern edge of the Nágera Terrace, is a steep scarp. At the base of this scarp is a wide moat. The moat's west side is cut by stubby gullies displaying meandering pattern (Fig. 19). The moat ends abruptly against the south side of one of the tributaries of Canyon 3. The seafloor between canyons 3 
and 4 is occupied by lenticular and butterfly shaped scours with the northernmost one being truncated by canyon 4 (Fig. 2B). We infer that all these features are the products of the north flowing Falkland/Malvinas Current, a surficial geostrophic current that interacts with the seafloor at those depths. There is no evidence of the moat between Nágera and Perito Moreno terraces north of Canyon 4 with only a low relief slope separating them (Fig. 18). South of Canyon 2 the area between the terraces consists of a NW trending ridge surrounding by moats and hollows and a southwest-northeast trending low whose western edge is cut short stubby gullies trending E-W (Fig. 18).

The possible presence of a BSR at the southern end of the moat, the possible diapir like structures west of the moat and a possible pockmark west of the moat that may have been deepened by bottom currents suggest that gas/water expulsion has played a role in the formation of the moat (Fig. 7B). According to Lastras et al. (2011) the crescent scours with their steep southern sides within the moat were formed by strong north flowing along the slope bottom currents. They are probably the creations of the north flowing Antarctic Intermediate Water (AAIW). Coriolis Effect caused the north flowing current to deflect to the left in the southern hemisphere, constraining the flow against the scarp separating the Nágera and Perito Moreno terraces. As a result of this constraint the flow intensified leading to erosion of the scarp and exposure of an Eocene lutite and younger sediments beneath the Nágera Terrace surface (Fig. 7A), the formation of the moat at its base and the scour structures along the moat axis. Lower velocities to the right of the flow led to the deposition of the sheet drift blanketing the Perito Moreno Terrace (Fig. 7B).

Another example of bottom current generated topography on the Nágera Terrace is the hollows in the low between canyons 2 and 1 (Figs. 18 and 20) and the moats surrounding the northwest trending ridge in this low (Fig. 8). We speculate that as a result of this ridge the bottom current was diverted eastward cutting the hollows and moats in the vicinity of the ridge. The stubby gullies at the western end of this complex terrain indicate that down-slope processes also contributed to the formation of the topography (Fig. 18). 
The east-west oriented current generated features on the surfaces of the terraces are much smaller, and may be more appropriately labeled as waves. These features were formed on the surfaces of sheeted drifts. The 3D diagram constructed from the multi-beam data imaged the sheeted drifts with their wavy tops on the surfaces of the Nágera and Perito Moreno terraces (Fig. 19) and divides between canyons in this area (Fig. 2B).

Bottom current generated features also occur on the slope separating the Perito Moreno and Piedra Buena terraces that can be traced from the southern margin of our survey area to just north of Canyon 4 where it disappears beyond the eastern limit of our survey area (Fig. 2B). Current generated features along this terrace boundary are different from those along the Nágera/Piedra Buena terraces. They consist of a series of steps that descend eastward and sediment drifts with undulating tops resting on them. A slightly convex step south of Canyon 1 descending to the Piedra Buena Terrace displays numerous gullies cut into sediment drift. This erosion probably is due to sediments cascading downslope (Fig. 9-1). Pockmarks formed by the expulsion of gas/water also cut the scarp along the eastern side of Perito Moreno Terrace (Fig. 18).

In addition the terrace also is cut by a narrow depression that may be linked to Canyon 0 via a faint channel cut into the western edge of terrace Moreno Terrace (X, Figs. 2B, 6 and 18). Also present on one of the steps are scour depressions elongated in the direction of the north-south currents (Fig. 19). All in all the extensive Eocene outcrops covered by a veneer of Pleistocene crafted sediments, such erosive forms as hollows, moats, and pot holes and extensive fields of sediment waves and sediment drifts indicate that northward flowing geostrophic currents have been major agents in sculpturing the morphology of most of the middle slope.

Although deposition of the drift unit has diminished the relief along the eastern edge of the Perito Moreno Terrace north of Canyon 2 by filling some of the topographic low (Fig. 12), the canyons are unfilled (Fig. 2B). How the canyons been kept open in spite of the sediment that may have carried across them is to be resolved. Maybe the canyons are periodically kept clean by turbidity currents that 
sweep down the canyons. If such currents are taking place they are not from sediments being deposited on the outer shelf today. The shelf is probably too wide for any cross-shelf transport from land sources and the presence of relict sands along the outer shelf is a further indication that modern sediments are not reaching the outer shelf.

Another way that turbidity currents could be triggered today is by deposition of high-upwelling-driven productivity around the canyon heads. If episodic turbidity currents are not responsible for keeping the canyons open, then possibly they have remained unfilled as part of the UCDW is captured by the canyons as it crosses them and forced down canyon. This down canyon flow is the mechanism that keeps the canyons sediment free. Such is the process that has been suggested by Marchès et al. (2007) for the preservation of Portimão Canyon in the Gulf of Cadiz. Yet that is only one canyon whereas in the Patagonian margin such process supposedly is responsible for the preservation of 7 canyons. Also the dimensions of the canyons relative to the magnitude of the UCDW suggest that their impact on the bottom circulation should be minor. Another mechanism that may keep canyons open are tidal currents. According to Shanmugam (2003) such currents can attain maximum velocities of 25-50 cm/s and Keller and Shepard (1978) reported velocities as high as 70-75 cm/s, velocities capable of transporting coarse sands. Possibly the canyons are younger than the drifts which would indicate that drifts were formed under different oceanographic conditions that existed at that time the canyons were cut. Such a possibility is suggested by the erosion of Canyon 1 along the contact between a sediment drift in the low between canyons 1 and 2 and the massif between canyons 1 and 0 (Fig. 22).

\subsubsection{Down- Slope Processes}

\subsection{2a Submarine Canyons}

Lastras et al. (2011) inferred that down and along-slope processes in the Patagonia slope occurred at the same place and the same time. They stated that across-slope processes were dominant in the Nágera 
Terrace whereas the Perito Moreno Terrace was mainly the domain of along-slope one. From these and other observations on the morphology of the middle slope they infer that the canyons began as scours formed along-slope processes. These incipient canyons grew up the middle slope by retrogressive erosion with some terminating on the upper middle slope, others on the upper slope and one breaching the shelf edge.

That the upper slope does not display any topographic irregularities that could reflect the pathways of sediments down the upper slope to the middle slope (Fig. 3) lends further support to Lastras et al. (2011) contention hat the canyons grew upslope. The irregularities on the upper slope consist of grooves that may have been formed by the joining of pockmarks, high reflective very small highs that may represent iceberg drop stones and undulating grooves that may represent icebeg plow marks.

The 3D's created from the multi-beam data also indicate that some of the gullies that fed the canyons (canyons 0, 1 and 2) have their heads in the field of iceberg plow marks in the upper slope and the upper middle slope (Fig. 3). The gullies feeding Canyon 3 either have their heads along the east side of a belt of smooth reflective seafloor flanking the plow marks, or within it, and canyons 4 and 5 extend to the lower upper slope having plow marks oriented parallel to its strike. The head of Canyon 4 displays N-S trending stubby rills that apear to have been formed by preferential erosion along the iceberg plow marks (Fig. 3). Canyon 5 head is funnel-shape, morphology, like in Canyon 4, created by preferential erosion along N-S trending plow marks. The heads of the two southernmost of the tributaries of Canyon 6 are at the foot of the upper slope and appear to be located at the northern end of the iceberg plow marks.

These relationships suggest that these icebergs were the sediment source for canyons $0,1,2$ and 3 with their sudden melting leading unstable slope conditions prone to down-slope sediment flows. The heads of canyons 4, 5 and 6 appear to have been formed by a combination of westerly and northerly directed erosion after the icebergs melted or migrated northward. If we are correct in our assumption that the iceberg plow marks are 1.0 Ma old then these sections of canyons 4-6 are younger than 1.0 Ma. The 
gullies that served as a feeders from the icebergs in canyons 0-3 are so poorly developed that if the icebergs were the sole sediments source for these canyons the amount of detritus provided by them must have been small. These relationships lead us to infer that the canyons, after they formed, did not served as major pathways for the transport of sediment from the continent to the deep-sea and are not active at present. They probably only served as conduits for detritus carried northward by bottom currents that was or is trapped by the canyons.

The presence of pockmarks in the vicinity of Canyon 0 (Fig. 18) suggests that possibility that gas/water expulsion may have played a role in its formation. Canyon 4 also may have a complex history of retrogressive erosion and pockmark amalgamation. The presence of pockmarks in the vicinity of the head of this canyon suggests that expulsion of gas/water also has played a role in the formation of the head of the canyon. Pockmarks in a mushy bottom in the vicinity of a tributary of Canyon 4 display linear trends (Fig. 13).

Jobe and Lowe (2009) proposed that these trains are formed when a submarine canyon is abandoned and is filled by fine-grained sediments. These abandoned canyons first developed cross-canyons ridges and the ridges in turn evolve into peanut-shaped double pockmarks and later into pockmarks aligned into a train. The presence of channels east of the pockmark chain in the vicinity of Canyon 4 supports such an origin. However, such linear trends also could be the result of biological activity (Heezen and Hollister, 1971). A bioturbation origin for the pockmarks is supported by the mushy texture of the seafloor in the vicinity of the tributary of Canyon 4, a texture suggestive of bioturbation. Possibly the pockmarks on the shelf also may be of biogenic origin, an origin supported by their association with a sediment unit whose margins displays characteristics of a recent flow over the shelf sands (Fig. 3). However, the "bubble" texture imaged in Fig. 11B also has been describe from the Persian Gulf, a texture that Ellis and McGuinness (1986) ascribed to the slow migration of small volumes of gas through the bottom.

\subsection{2b. The Low Between Canyons 1 and 2}


The SW-NE trending low between canyons 1 and 2 appears to have a complex history of along and down-slope processes (Fig. 18). It is partially filled with sediment drift with a gullied high scarp along its western side (Figs. 5C and 18). The surface of the drift is characterized by SW-NE trending sediment waves, SW-NE, NW-SE, W-E and N-S trending U-shaped hollows. We differentiate hollows from moats in that the former were eroded on a smooth floor whereas the latter were cut along the base of a slope; both are short and are not linked to any gully generated by down-slope processes.

The ridge extending northwestward from the low is surrounded by moats at along its base (Fig. 2B; Fig 8). The sediment drift north of the ridge has partially filled the southern tributary of Canyon 2 and blankets the divide between the canyon and its tributary. A seismic reflection profile extending from north of Canyon 2 to south of Canyon 1 along the western edge of the low (Fig. 22A) shows that the seafloor between Canyon 2 and the low is covered by sediment drift, the low is V-shaped in cross with an irregular northern flank and a smooth southern one cut into a sediment drift and unit below it displaying strata dipping in the direction of the low and underlained by a strong reflector that extends across the low with Canyon 1 at its southern end being flanked by the sediment drift on the north and the massif extending from Canyon 1 to Canyon 0 on the south.

This profile demonstrates that the low is eroded out of drift and the strata beneath it. Its V-shaped suggests that at least part of the low was formed by down-slope processes. The low along a profile on its eastern side (Fig. 22B) consists of three flat-topped highs mantled by drift and separated by lows that we inferred are current generated hollows. It is the presence of these U-shaped hollows, rather than Vshaped gullies that has led to postulate that the low has a complex history. Possibly the low was eroded in Late Miocene by turbidity currents, it was later filled by sediment drift and later was partially exhumed during the Late Pleistocene by bottom currents and down-slope turbidity currents that cut its western edge. It was at this time that Canyon 1 was cut along the contact between the sediment drift filling the low and the massif between canyons 1 and 0 (Fig. 22). 


\subsection{2c. The lows Along the East Side of Perito Moreno Terrace}

The lows orthogonal to the scarp separating the Perito Moreno and Piedra Buena terraces, that Lastras et al. (2011) interpreted as incipient canyons, also may have a more complex origin. The lows may have undergone two distinct phases of canyon cutting (Fig. 12). Thus, the development of the lows may have involved canyon cutting or slumping, filling of the low by sediment drift and a recent canyon cutting of the drift. Possibly the first canyon/slumping phase took place during the formation of the terraces by bottom currents in late Miocene. Filling of the low may have taken place in the Pliocene and the second phase of canyon cutting in Late Pleistocene.

\subsection{2d. Sediment Swell}

Another topographic feature formed by down-slope processes is the sediment swell onlapping the upper middle slope whose surface forms the South Nágera Terrace (Fig. 2B). The multi-beam data do show that, the surface of the swell (South Nágera Terrace) is smooth and lacks the current generated features found farther north, except for the isolated northeast groove at the southern end of the surface area, the plow marks on its western side and few isolated pockmarks on its eastern side (Fig. 2B). The plow marks cutting its western side demonstrate that the swell is preLate Pleistocene. The possibility that the Eocene lutite cored by Ewing and Lonardi (1971) may correlate with Unit 1 below Horizon U1 (Fig. 10) would suggests that Unit 2 making the bulk of the unit is Oligocene-Miocene with Units 3-4 resting unconformably on Unit 2 being PlioceneQuaternary in age.

The configuration of the swell also suggests that these sediments were derived from the west with possibly the Chaco, Chico and Deseado rivers being the sources to the detritus (Fig. 1). These 
rivers originate in the Andes and discharges into the South Atlantic from just north of $44^{\circ} \mathrm{S}$ to just north of $48^{\circ} \mathrm{S}$. Dates of the basalts interbedded with glacial sediments indicate that the Andes were glaciated during the Late Miocene-Early Pliocene, Pliocene and Late-Pliocene and Early and Late Pleistocene with the ice extending eastward onto the Patagonian plains (Mercer, 1983). At those times those rivers must have been major sediment contributors to the Patagonian margin forming outwash plains on the coast and any segment of the shelf that it was exposed as proposed by Zárate (2003) for the Late Pleistocene. It was sediments from these plains that may have been the source of the sediment swell whose proximal end onlaps the upper middle slope. Thus it can be considered to be a fan (Fig. 20).

The seismic reflection lines in Fig. 11 show the same tectonic pattern, extension upslope, compression northward in the southern flank of Canyon 0 and a massif between canyons 0 and 1 that lacks stratification. This absence of stratification could possibly is due to the presence of free gas that is obscuring its bedding. Canyon 1 appears to have been eroded along the contact between this massif and sediment drift to the north (Fig. 22A). The figures 11 and 17-4 image the magnitude of the compression along the northern flank of Canyon 0, a compression that must have played a role in the formation of the canyon. All in all the tectonic style appears to be one of gravitational tectonics with compression due to collision against the massif between canyons 1 and 0 . This northerly directed sliding is manifested in the arc shape of the axis of Canyon 0 suggesting that the canyon was eroded along the northern edge of this massive slide.

West of $60^{\circ} \mathrm{W}$ the deformation along the northern edge of the swell appears to be due to diapirism and fluid venting (Fig. 14). As there is no evidence that the Patagonian margin is underlained by Mesozoic evaporites or is the sediment cover intruded by igneous bodies (Franke et al., 2007), gas saturated and overpressured muds must be the mobile medium responsible for the intrusions. The only cross-slope structural feature in the area is the western extension of the Falkland/Malvinas Fracture Zone along the northern edge of the Falkland/Malvinas Plateau. 
Max et al. (1999) inferred from magnetics that it trended E-W and Franke et al. (2007) proposed, from multi-channel seismic data, that it trended NW-SE (Fig. 1). If the features along $47^{\circ} \mathrm{S}$ are due to activity along the fracture zone, trends E-W, as suggested by Max et al. (1999). As free gas and hydrate gases are diffused in the shallow stratigraphic levels of the region, as indicated by the pockmarks, gas wipeouts, local uplifts and vents, vertical migration of such overpressure fluids also may have been a major contributor to the syn-sedimentary deformation.

The other intriguing feature of the swell is the lack of the bottom current and turbidity current irregularities on its surface found north of the swell. Its high organic content (2-4\% south of $47^{\circ} \mathrm{S}$ versus 2 to $0.47 \%$ north of this latitude; Proyecto ATLANTIS, 2009) suggests that the region is one of deposition in a low energy environment. A high oriented at or nearly at right angles to the north flowing current, Falkland/Malvinas Current, should have been as deeply eroded as the middle slope to the north was yet it is not.

\subsection{Fluid Migration}

Circular depressions, pockmarks, formed by the expulsion of gas/water, gas wipeouts, gas chimneys, diapirs and possibly carbonate mounds formed from methane-derived authigenic carbonates, and a broad swell along the north side of Canyon 4 occur on the middle slope. The wide expanse of these features on the Atlantic Patagonian shelf and upper and middle continental slope indicate that endogenic processes have played a role in creating the morphology of the Patagonian shelf and slope. Contrary to Cavallotto et al. (2011) supposition that endogenic processes only occurred in the Patagonian slope during the rifting and early opening of the South Atlantic, endogenic processes are still active or were active recently in the region.

Since King and MacLean (1970) first described pockmarks from the Scotian Shelf, they have been reported from many environments (Uchupi et al., 1996 and references therein). It is this 
diverse distribution that led Paull et al. (2002) to infer that pockmarks are probably not due solely to the expulsion of gas and fluids, but are formed by a variety of mechanisms. However, their association with gas wipeouts, acoustic masking, reflector enhancement and gas chimneys imaged in the seismic reflection profiles, has led us infer that most of the depressions in the Atlantic Patagonian shelf and slope are created by fluid/gas expulsion. Some of the pockmarks are associated with iceberg plow marks suggesting that extrusion of the fluid/gas may have been triggered by the impact of icebergs on the seafloor.

Free gases and hydrate gases not only created their own unique features, but gas expulsion influenced the formation of forms by other processes, scours by bottom currents and possibly two submarine canyons, 0 and 4 . Acoustic chimneys occasionally are found in association with some of the pockmarks. Weak reflectors found within two of the vents in Fig. 14A are downwarped. In contrast, Horazal et al. (2009) reported that the weak reflectors within the seismic chimneys in the Sea of Japan are upwarped. They proposed that this warping there was due to either thermal, thermo-chemical effects or to a velocity effect of massive, shallow gas hydrate lenses that causes velocity pull-ups. The downwarp in the Patagonian slope could be a consequence of a decrease in compressive velocity caused by some chemo-thermal anomaly caused by fluid migration within the vent.

Pockmarks are particularly extensive in the area of Canyon 0 forming a belt extending from the base of the upper slope to the western edge of the Perito Moreno Terrace. It is along this belt that the gravitational structures along the north side of the sediment swell are imaged in Fig. 11. It is also at the western end of this belt that there is zone of diapirism (Fig. 14) with the crests of the sediments folded by mud diapirism forming low relief mounds at the head of Canyon 0 (Fig. 18). Possibly the uplifted features in Figs. 7B, 14A and 15 that are not associated with intrusives, may represent mega blisters formed by expansion caused by gas hydrates lenses in the subsurface in the manner described by Paull et al. (2008). However, the features in those profiles are much 
bigger than the blisters describe by Paull et al. (2008). If the local vertical displacements noted in these profiles are due to gas hydrate lenses in the immediate subsurface their volumes must be greater than that associated with the structures off southern California.

\section{Conclusion}

A multi-beam, bottom sample and bottom photograph survey of a segment of the continental shelf and upper and middle continental slope of Atlantic Patagonia, from $44^{\circ} 40^{\prime}$ S to $47^{\circ} 51^{\prime} \mathrm{S}$ and $58^{\circ} 52^{\prime} \mathrm{W}$ to $61^{\circ} 05^{\prime} \mathrm{W}$, coupled with low penetration high resolution seismic profiles have provided details on the morphology and processes on the outer shelf and the upper and middle continental slope that were poorly known.

The offshore Atlantic Patagonian segment investigated can be visualized as two platforms, shelf and middle slope, separated by a narrow upper continental slope. The shelf is 360-530 km wide at $44^{\circ} \mathrm{S}$ to $48^{\circ} \mathrm{S}$, has a gradient of less than $1^{\circ}$, the upper slope is 6 to $20 \mathrm{~km}$ wide, has a gradient in excess of $2^{\circ}$ and descends from the shelf edge at 150/200 m to 400-750 m and the middle slope is 50 to $150 \mathrm{~km}$ wide, has a gradient of less than $1^{\circ}$ and extends from a depth of $400-750 \mathrm{~m}$ to about $1400 \mathrm{~m}$. Although plowing by icebergs affected the lower upper and upper middle during the Pleistocene and ice rafted sediments were deposited throughout much of the upper and middle slope, the main processes that have molded the seascape of these surfaces are along and down-slope. Internal forces played a secondary role.

These forms were sculptured during two periods. Under the influence of the northeast flowing Falkland / Malvinas Current, two terraces were cut on the middle slope in Late Miocene. One, Nágera Terrace, extends from the base of the upper slope to a depth of 940 to $1060 \mathrm{~m}$ and the other, Perito Moreno Terrace, extends from a depth of about 1100/1200 to $1400 \mathrm{~m}$. The terraces are separated by a high scarp and a wide moat at the base of the scarp. The eastern edge of the 
Perito Moreno Terrace is characterized by a series of steps that descend to another terrace, the Piedra Buena Terrace at a depth of about 2100 to $2500 \mathrm{~m}$.

Features formed during the Pleistocene extend from the outer shelf at a depth of less than $200 \mathrm{~m}$ to about 1400 m on the eastern edge of the Perito Moreno Terrace. Late Pleistocene current generated features on the outer shelf consist of gravelly sand ridges oriented oblique to the shelf edge. They are separated by troughs opened to the southwest do not appear to be active and are probably related to the time when sea level was much lower. Possibly it was at that time that the lower part of the Nágera Terrace scarp and moat separating the Nágera and Perito terraces experienced extensive erosion by bottom currents leading to the form of pot holes, scours hollows, stubby gullies along the west side of the scarp and moats along the sides of topographic highs. Most of Perito Moreno Terrace is covered by sediment drifts in the form of sheets, mounds and plastered against highs.

Features created by down-slope processes include a sediment swell at the southern end of the survey area and submarine canyons. This swell whose construction began in pre-Late Pleistocene was built by east draining rivers originating in the Andes, possibly in the Miocene-Pliocene when the mountains were glaciated. The northern edge of the swell experienced gravitational failure possibly as a result of rapid sedimentation or uplift, an uplift possibly due to activity along the western prolongation of the Falkland/Malvinas Fracture Zone.

Another feature of the middle slope due to down-slope processes are seven canyons only one of which cuts the outer shelf. The others terminate either at the base of the upper slope or in the upper middle slope. Lastras et al. (2011) have proposed that these canyons were formed by bottom current generated scours that acted as a depository of across-slope transported sediment, that these scour, as a consequence of flow focusing, became connected to form gullies that grew to canyons. As a result of retrogressive erosion the canyons grew up the middle slope with one breaching the outer shelf. Canyon 0 , the southernmost canyon, may have a different origin. The 
wide extent of gas generated pockmarks in the vicinity of the canyon and the compressive structures along its southern edge suggest that the canyon was forced by these two processes. Possibly such gas expulsion also played a role in the formation of the head of Canyon 4. We speculate that current induced shelf spillover processes today are of minor importance. Consequently there is little down-slope sediment movement on the upper and middle slope today, and the Falkland/Malvinas Current is slowly remolding the seafloor of the slope.

\section{Acknowledgements}

Thanks are due to the Captain, officers and crew of R/V Miguel Oliver (Secretariat General of Fisheries, SGP) for their efforts and high professionalism during the cruises to the Patagonian margin. We also extend our gratitude to the SGP, who provided the ship time and technical support and to the members of the Spanish Oceanographic Institute (IEO) who participated in the cruises. We are indebted to the colleagues of the Cartography Group TRAGSA- SGP who participated in the different cruises and processed the multi-beam data. Appreciation is expressed to Steve Swift of the Geology and Geophysics Department of the Woods Hole Oceanographic Institution. Numerous discussions with him during the writing of this paper were most helpful. We acknowledge to two anonymous reviewers for the throughout revision of the manuscript, that improved the final result. Thanks also to Andrew D. Miall editor of the journal for his revision and help.

This is a contribution to Atlantis Project, which is funded by IEO in collaboration with SGP.

\section{References}

Arkhipkin, A.I., D.A.J. Middleton, D.A.J.,A.M. Sirota, A.M., Grzebielec, R., 2004. The effect of Falkland Current inflows on offshore ontogenetic migrations of the squid Loligo gahi on the southern shelf of the Falkland Islands. Estuarine, Coastal and Shelf Science 60(1): 11-22.

Burckle L.H., Hays J.D., 1974. Pre-Pleistocene sediment distribution and evolution of the Argentine continental margin and Falkland Plateau (Abs). Geological Society of America Annual Meeting. Abstracts with Programs: 673-674. 
Cavallotto, J., Violante, R., Hernántez-Molina, F.J, 2011. Geological aspects and evolution of the Patagonian continental margin. Biological Journal of the Linnean Society 103: 346-362.

Cieselski, P.F., Ledbetter, M.T., Ellwood, B.E., 1982. The development of Antarctic glaciation and the Neogene environment of the Maurice Ewing Bank. Marine Geology 46: 1-51.

Conway, K.W., Barrie, J.V., Krautter, M., 2005. Geomorphology of unique reefs on the western Canadian shelf: sponge reefs mapped by multibeam bathymetry. Geo-Marine Letters 25: 205213.

Ellis, J.P., McGuinnees, W.T., 1986. Pockmarks of the northwestern Arabian Gulf. Advances in Underwater Technology, Ocean science and Offshore Engineering. Oceanology 6: 353-367. Ewing, M, Lonardi, A.G., 1971. Sediment transport and distribution in the Argentine Basin. 5. Sediment structure of the Argentina margin, basin, and related provinces. In: Ahrens, F. Press S.K.Runcorn, H.C.Urey (Editors), Physics and Chemistry of the Earth 8. New York: Pergamon Press;1971. P. 123-251.

Faugères, J-C, Stow, D.A.V., 2008. Contourite drifts, nature, evolution and controls. In; M. Rebesco, A. Camerlenghi (Editors), Contourites. Developments in Sedimentology 60: 259-288.

Faugères, J-C, Stow, D.A.V., Imbert, P, Viana, A., 1999. Seismic features diagnostic of contourite drifts. Marine Geology 162: 1-38.

Flood, R.D., Shor, A.N.,1988. Mud waves in the Argentine basin and their relationship to regional bottom circulation patterns. Deep-Sea Research 36: 943-971.

Franke, D. Neben, S., Ladage, S., Schreckenberger, B., Hinz, K., 2007. Margin segmentation and volcano-tectonic architecture along the volcanic margin off Argentina/Uruguay, South Atlantic. Marine Geology 244: 46-67.

Fray, C., Ewing, M.,1963. Pleistocene sedimentation and fauna of the Argentine shelf. I. Wisconsin sea level as indicated in the Argentine continental shelf sediments. Proceedings of the Academy of Sciences of Philadelphia 115: 113-116. 
Groot, J.J., Groot C.R., Ewing M., Burckle L., Conolly J.R., 1965 Spores, pollen, diatoms and provenance of theArgentine Basin sediments. Progress in Oceanography 4: 179-217.

Hanna, G.D., Henley H.I., Brigger, A.L, 1976. Some Eocene diatoms from South Atlantic cores. Part 1. New and rare species of Arachnoidiscus. California Academy of Sciences Occasional Papers 123: 1-19.

Heezen, B.C., Hollister, C. 1971 The Face of the Deep. Oxford University Press, New York, 759 pp. Hernández-Molina, F.J., Paterlini, M., Violante, R., Marshall P., Isasi, M., de Somoza, L., Rebesco, M., 2009. Contourite depositional system on the Argentine Slope: an exceptional record of the influence of the Antarctic water masses. Geology 37: 507-510.

Hernández-Molina, F.J., Paterlini M., Somoza L., Violante R., Arecco M.A., de Isai M., Rebesco M., Uenzelmann-Neben, G, Neben S, Marshall P., 2010. Giant mounded drifts in the Argentine continental margin: origins, and global implications for the history of thermohaline circulation. Marine and Petroleum Geology 27: 1508-1530.

Hinz, K., Neben S., Schrenckenberger D., Roeser, H.A., Bloc, M., Gocalves de Souza K., 1999. The Argentine continental margin north of $48^{\circ} \mathrm{S}$ : sedimentary succession, volcanic activity during breakup. Marine and Petroleum Geology 16; 1-25.

Horozal, S., Lee, G.H., Yi, B.Y., Yoo, D.G., Park, K.P., Lee, Ho, Y., Kim W, 2009. Seismic indicators of gas hydrate and associated gas in the Ulleung Basin, East Sea (Japan Sea) and implications of heat flows derived from depths of bottom-simulating reflector. Marine Geology 258: 126-138.

Hovland, M., Croker, P.F. Martin, M., 1994. Fault-associated seabed mounds (carbonate knolls?) off western Ireland and north-west Australia. Marine Petroleum Geology 11: 232-246.

Jobe, Z.R., Lowe, D.R., 2009. Pockmarks on the modern seafloor as indicators of submarine canyon abandonment, offshore Equatorial. AAPG Search and Discovery Article \#90088@2009 Pacific Section Meeting, Ventura, California, May 3-5, 2009.

Keller, G.H., Shepard, F.P., 1978. Currents and sedimentary processes in submarine canyons off the northeast United States. In: D.J.Stanley, G.K.Kelling (Editors), Sedimentation in submarine 
canyons, fans, and trenches. Dowden, Hutchinson and Ross, Inc., Stroudsberg, Pennsylvania, pp. 15-32.

King, L.H, MacLean, B., 1970. Pockmarks on the Scotian Shelf. Geological Society of America Bulletin 81: 3141-3148.

Lagabrielle, Y., Goddéris, Y., Donnadieu Y., Malaville, J.S., Sarez, M., 2009. The tectonic history of Drake Passage and its possible impacts on global climate. Earth and Planetary Science Letters 279: $197-211$.

Lastras, G., Acosta, J., Muñoz, A., Canals, M., 2011. Submarine canyon formation and evolution in the Argentine continental margin between $44^{\circ} 30^{\prime}$ S and $48^{\circ} \mathrm{S}$. Geomorphology 128: 116-136.

León R., Somoza, L., Medialdea, T., Maestro, A., Díaz-del Río, V., Fernández-Puga, M. del Carmen, 2006. Classification of sea-floor features associated with methane seeps along the Gulf of Cadíz continental margin. Deep-Sea Research II 53: 1464-1481.

Lonardi, A.G., Ewing, M., 1971. Sediment transport and distribution in the argentine Basin. 4. Bathymetry of the continental margin, Argentine Basin and other related provinces. Canyons and sources of sediments. In: L.H.Ahrens, F. Press, S.K. Runcorn. H.C.Urey (Editors), Physics and Chemistry of the Earth 8. Pergamon Press, New York. pp. 79-121.

López-Martínez J., Muñoz, A,, Dowdeswell, J.A., Linés, A., Acosta, J., 2011. Relict sea-floor plowmarks record deep-keeled icebergs to $45^{\circ} \mathrm{S}$ on the Argentine margin. Marine Geology 288: 43-48.

Marchès E., Mulder T, Cremer M., Bonnel, C, Hanquiez V, Gonthier E., Lecroat P. Contourite drift construction influenced by capture of Mediterranean Outflow Water deep-sea current by the Portimão submarine canyon 9Gulf of Cadiz, south Portugal). Marine Geology 2007; 242: 247260.

Matano, R.P., Palma E.D., 2008. On the upwelling of downwelling currents. Journal of Physical Oceanography 38: 2482-2500. 
Matano, P., Palma, E.D., Piola, A.R., 2010. The influence of the Brazil and Malvinas currents on the southwestern Atlantic shelf circulation. Ocean Science Discussion 7: 837-871.

Max, M.D., Ghidella, M., Kovacs, L., Paterlini, M., Valladares, J.A. 1999. Geology of the Argentine continental shelf and margin from aeromagnetic survey. Marine and Petroleum Geology 16: 4164.

Mercer, J.H., 1983. Cenozoic glaciation in the Southern Hemisphere. Annual Reviews Earth Planetary Science 1, 99-132.

Magalhães, V.H., Pinheiro, L.M., Ivanov, M., Kozlova, E., Blinova, V., Kolganova, J., Vasconcelos, C., McKenzie, J.A., Bernasconi, S.M., Koft, A., Díaz-del Río, V., González, F.J., Somoza, L., 2012. Formation processes of methane-derived authigenic carbonates from the Gulf of Cadiz. Sedimentary Geology 243-22: 156-168.

Muñoz, A., Cristobo’ J., Ríos, P., Druet, M, V. Polonio, V., Uchupi, E., Acosta, J., and Atlantis Group, 2012. Sediment drifts and cold-water coral reefs in the Patagonian upper and middle continental slope. Marine and Petroleum Geology 36: 70-82

Parker, G., Nafredi, N.W., Swift D.J.P., 1982. Seafloor response to flow in a Southern Hemisphere sand-ridge field; Argentine inner shelf. Sedimentary Geology 33: 195-216.

Parker, G., Violante, A., Paterlini, MC., 1996. Fisiografía de la plataforma continental. In: V.A.Ramos, M. Turic (Editors). Geología y Recursos Naturales de la Plataforma Continental Argentina. XIII Congreso Geológico Argentino; III Congreso de Exploración de Hidrocarburos, Buenos Aires, Argentina, pp. 1-16.

Paull C., Ussler III W., Maher, N., Greene, H.G., Rehner, G, Lorenson, T, Lee H., 2002. Pockmarks off Big Sur, California. Marine Geology 181: 322-335.

Paul C.K., Normark, W.R., Ussler, W III, Caress, D.W., Keaton, R., 2008. Association among active seafloor deformation, mound formation, and gas hydrate growth and accumulation within the seafoor of the Santa Monica Basin, offshore California. Marine Geology 250: 258-275. 
Piola, A.R., Matano, R.P., 2001. Brazil and Falklands (Malvinas) currents. In: J.M.Steele, S.A. Thorpe, K.K., Turekian (Editors), Encyclopedia of Ocean Sciences. New York, Academic Press, pp. 340-349.

Proyecto ATLANTIS, Undated. Informe preliminar sobre ecosistemas marinos vulnerables en aguas internacionales del Atlántico Sudoccidental y las posibles interacciones con las actividades pesqueras. Unpublished Report of the Instituto Español de Oceanografia, Madrid, Spain, 157 pp.

Shanmugam, G., 2003. Deep-marine tidal currents and their reworked sands in modern and ancient submarine canyons. Marine and Petroleum Geology 20: 471-491.

Uchupi, E., Swift, S.A., Ross, D.A., 1996. Gas venting and late Quaternary sedimentation in the Persian (Arabian) Gulf. Marine Geology 129: 2327-269.

Zárate, M.A., 2003. Loess of southern South America. Quaternary Science Reviews 22: 1987-2006. 


\section{Figure Captions}

Fig. 1. Map of the Patagonian margin, showing the location of the survey area. Also shown are the zone of compression from Fig. 20 and the possible western extension of the Falkland/Malvinas Fracture Zone; A: according to Franke et al. (2007) and B: according to Max et al. (1999).

Fig. 2. A: Distribution of high-resolution seismic reflection profiles (TOPAS) recorded in the Atlantic Patagonian margin. B: Bathymetric map of a segment of the Atlantic Patagonian margin compiled from multi-beam data acquired during the present investigation. Canyons cutting across the slope are labeled with Arabic numbers 0-6. Contour interval 50 m. G=Gully; H=High; M=Moat; MET=Maurice Ewing Terrace; MS=Middle slope; NT=Nágera Terrace; $\mathrm{P}=$ Circular depressions (pockmarks); $\mathrm{PMT}=$ Perito Moreno Terrace; P1=Ellipsoidal shaped depressions; PL=Iceberg Plow Marks; R=Ridge; R/T=Ridges and troughs; S=Shelf; SC=Slump Scar or Incipient Canyon; SN=South Nágera Terrace (top of sediment swell); SR=Sediment Rise; SW=Swell (Fan); T=Terrace; US=Upper Slope. X=Depression.

Fig. 3. Digital Terrain model of the shelf, upper and upper middle slope. Arabic numbers represent submarine canyons cutting the slope. D=Iceberg drop stones; IP=Iceberg plow marks; G-Gullies; $\mathrm{P}=$ Pockmarks: $\mathrm{SR}=$ Sediment ridges.

Fig. 4. A. Seismic reflection profile from the Patagonian outer continental shelf. LSR=Sand ridge; $\mathrm{R}=$ Ravinement unconformity associated with the last post-glacial transgression. Hinz et al. (1999) dated the sequence below the ravinement surface as Middle Miocene and younger. B. Seismic reflection profile of a $1.0 \mathrm{~km}$ wide depression on the continental shelf with a diapir (D) in its center. The hills west of the pockmark represent exposures of the strata below the ravinement surface. The acoustic transparent column above the diapir is probably a gas vent. See Fig. 6 for location of profiles. 
Fig.5. A-B. Seismic reflection profile of the upper slope and Nágera Terrace in the upper middle slope. The terrace displays four steps (A-D). Irregularities on step A represent iceberg plow marks. The sediments in step D are divided into three units by two unconformities (U). Whereas the topography of steps A-C probably are due to down-slope processes that of D may be due to along-slope processes. C. Seismic reflection profile on the west side of the low south of Canyon 2. The unit within the low at the eastern end of the profile is a sediment drift, but the units on the platform west of the low are probably created by down-slope processes. The eastern end of this sequence experienced erosion by bottom currents leading to the creation of the scarp along the east side of Nágera Terrace. See Fig. 6 for location of profiles.

Fig.6. Shaded bathymetric map of the Atlantic Patagonian margin showing the locations of the figures and seismic reflection profiles. E=Locations of cores recovered by Ewing and Lonardi (1971) containing Eocene sediments; $\mathrm{X}=$ Depression that may be connected to Canyon 0 by poorly defined gully cutting the scarp along the east of the Perito Moreno Terrace.

Fig. 7 A. Seismic reflection profile of the northern end of the middle slope moat just south of Canyon 4. Eocene lutite was cored from the scarp on the west side of the moat by Ewing and Lonardi (1971). Erosion west of the moat probably is due to bottom currents with the unconformities (U) indicating that this erosion was cyclic. B. Seismic reflection profile of the N-S trending moat and the scarp on its west side separating the Nágera and Perito Moreno terraces. We infer that the strong reflecting horizon (U) northeast of the moat may represent the top of the Eocene lutite cored by Ewing and Lonardi (1971). Black arrows= area of uplift possibly due to subsurface gas hydrate lenses; BSR?=Bottom Simulating Reflector P?= Pockmark? Enlarged by bottom currents or H? hollow eroded by bottom currents; U=Unconformity. See Fig. 6 for location of profiles. 
Fig.8. A. 3D imaging of the NW- SE oriented ridge (R) south of Canyon 2. B: locations of topographic profiles 1-3 of the ridge displayed at the bottom of the panel. C. Profiles of the ridge. A=Artifacts; CS=Continental shelf; HO=Hollow; M=Moat. See Fig. 6 for location of 3D.

Fig.9. Seismic reflection profiles along the eastern edge of the Perito Moreno Terrace. The profile in the panel 1 images a plastered sediment drift whose erosion at the NNE end of the profile created a ridge and trough terrain oriented east-west. These gullies were probably cut by down-slope processes. In panel 2 (and blow up) the sediment drift, rest on a strong reflecting horizon that may represent the Eocene lutite cored by Ewing and Lonardi (1971) west of the profile. The drift is cut by vertical structures that may represent chimneys of rising gas. $\mathrm{U}=$ Unconformity; R/T Ridges and Troughs. See Fig. 6 for location of profiles.

Fig. 10. Seismic reflection profile extending eastward along the sediment swell (South Nágera Terrace). Units making the swell are divided by two by unconformities (U1; U2). The eastern end of Unit 2 (blow up) is disrupted by compressive features and vertical columns. We inferred that the columns are gas vents that originated in Unit 1. See Fig. 6 for location of profile.

Fig. 11. A: Top panel: N-S trending seismic reflection profile of the sediment swell south of $47^{\circ} \mathrm{S}$ processed displaying instantaneous amplitudes. Lower Panel (A and B): Segments of the seismic reflection profile in the upper panel. The up dip section of Unit 2 that correlated with Unit 2 in Fig. 10. Down dip units 2-3 are compressed, a deformation that terminates abruptly against the steep south side of Canyon 0. The north side of the canyon consisting of a massif lacking stratification possibly due to the presence of hydrates lenses or free gas (see text). B: Top Panel: N-S trending seismic reflection profile of the swell. Lower panel displays segments of the profile in the top panel. This profile displays 
an acoustic stratigraphy and similar to the upper (A) profile. Structures along this profile include folding, faulting, pockmarks and gas chimneys (white arrow). Compression along this profile terminates south of Canyon 0. C=Chimney; C0= Canyon 0; TR=Tributary of Canyon 0. U=unconformities; 14=Acoustic units. See Fig. 6 for location of profiles.

Fig. 12. Seismic reflection profile along at the scarp separating the Perito Moreno and Piedra Buena terraces. The low on the south side of the profile is filled by two sediment drift sequences separated by an unconformity (U). The high on the north side is stratified and is capped by sediment drift resting unconformable on the stratified lower unit. The low south of this high is partially filled by sediment drift. See Fig. 6 for location of profile.

Fig. 13. 3D of a tributary of Canyon 4 showing E-W (T) and N-S trending (L) pockmark trains and pockmarks (arrows) displaying a random distribution. See Fig. 6 for location of 3D.

Fig. 14. A: Seismic reflection profile showing folds and acoustic wipeouts. We infer that folding is due to intrusion of Unit 2 (black arrows) into the overlying strata. Rising from the crest of two of the intrusive and between two of them are gas vents (white arrows). Note layers in the vents bend downward probably due to a lowering of compressive velocity within the vents. Lack of stratification at the northern end of profile is due to acoustic wipeouts with uplift at the end of the profile possibly due to the presence of hydrates lenses as free gas would not lead to uplift. B: A well-developed diapir formed by the intrusion of layer 1 into the overlying units. We infer that this unit consists of mud. See Fig. 6 for location of profiles.

Fig. 15. Seismic reflection profile showing the moat at the base of the NW-SE trending ridge south of Canyon 2. The sediments of a high southwest of the moat are deformed with strata on its northeast side 
being warped and the strata on its southwest side being acoustically wipeout. We infer that this acoustic signature is due to a combination of free or subsurface hydrate lenses. Southwest of this complex structure is an asymmetrical moat eroded by bottom currents out of horizontal reflectors onlapping a strong reflector (Z) dipping northeastward. See Fig. 6 for location of profile.

Fig. 16. A. 3Ddigram of the several tens of meters high ridge (R) south of Canyon 2 where several dredges recovered deep-water coral. A=Artifact; HO-Hollow and M=Moat. B. Close-up of white box (B) in panel A showing cluster of mounds (CM?) in the vicinity of Canyon 2 that may represent carbonate mounds formed from the oxidation of methane.

Fig. 17. Seismic reflection profiles of canyons 0-1 displaying acoustic wipeout areas (AW) and irregular reflectors (BH1-BH3) that may represent relict bioherms associated with gases. AW=Acoustic Wipeout; Black Arrows=Mud Intrusive or areas where stratification is obscured by free gas or gas hydrate lenses; C0=Canyon 0; C1= Canyon 1; F-Fault; TR=Tributary of Canyon 0. White Arrow=subsurface pockmark and chimney See Fig. 6 for locations of profiles

Fig. 18. Digital terrain model of canyons 0,1 and 2. The morphology displayed by Canyon 0 suggests that pockmarks formed by the expulsion of gas/water have played a role in the formation of the canyon. Note that the gullies that act as feeders for the canyons begin in the field of iceberg plow marks. G=Gullies; H-Hollow; L=Low between canyons 1 and 2; M=Moat. MO=Mounds possibly formed by subsurface hydrate lenses in the manner described by Paull et al. (2008); NT=Nágera Terrace; P=Pockmarks; PM=Plow Marks; PMT-Perito Moreno Terrace; R=Ridge; ST=Steps eroded by bottom currents; SW=Sediment Swell; US=Upper Slope. 
Fig.19. A. An oblique 3D of canyons 2 and 3 and the moat linking them. Imaged by the 3D are the stubby gullies cutting the western rim of the moat. Note that one of the branches of Canyon $3(\mathrm{Y})$ has turned southward along the axis of the moat to join the southernmost branch of Canyon 3. Sections of Canyon 3 cut in the Perito Moreno Terrace and the Nágera Terrace are irregular and appear to be along scours trending northwest and northeast with the northernmost branches of Canyon 3 ending in a scour (W). B. Cross-section of sediment waves east of the moat. See A for location of profile.

Fig. 20. Schematic morpho-facies map of the Patagonian shelf/upper continental slope/middle continental slope compiled from multi-beam and seismic reflection data acquired during the present investigation.

Fig. 21. Bottom photographs of deep-water corals on the slope. The two calibrated red laser points are 5 cm apart. Yellow circles in upper panel shows the location of digital vertical camera stations CAM-13 and CAM-10. Lower panels’ images the high biologic diversity and presence of soft corals (Octocorals) on the upper slope $(\mathrm{B}, \mathrm{C})$ and cold water corals (Bathelia Candida) in the northwest trending ridge south of Canyon 2 (D, E).

Fig. 22. A: Seismic reflection profile displaying the stratigraphy from Canyon 2 to Canyon 1 . The area immediately south of Canyon 2 is mantled by sediment drift, the low between canyons 2 and 1 has a Vshaped cross-section suggesting down-slope processes, the area south of the low is mantled by sediment drift cut by a chimney formed by expulsed gas and Canyon 1 has been cut along the contact between this drift and a high whose stratification (Black Arrow) is obscured by free gas or gas hydrate lenses. B: Seismic reflection profile along the east side of the low between canyons 1 and 2 showing two flat top topographic highs covered by sediment drift separated by a U-shaped hollow cut by bottom currents. 
Sediments south of Canyon 1 shows are disrupted by a pockmark (P). U= Unconformities. See Fig. 6 for location of profiles. 


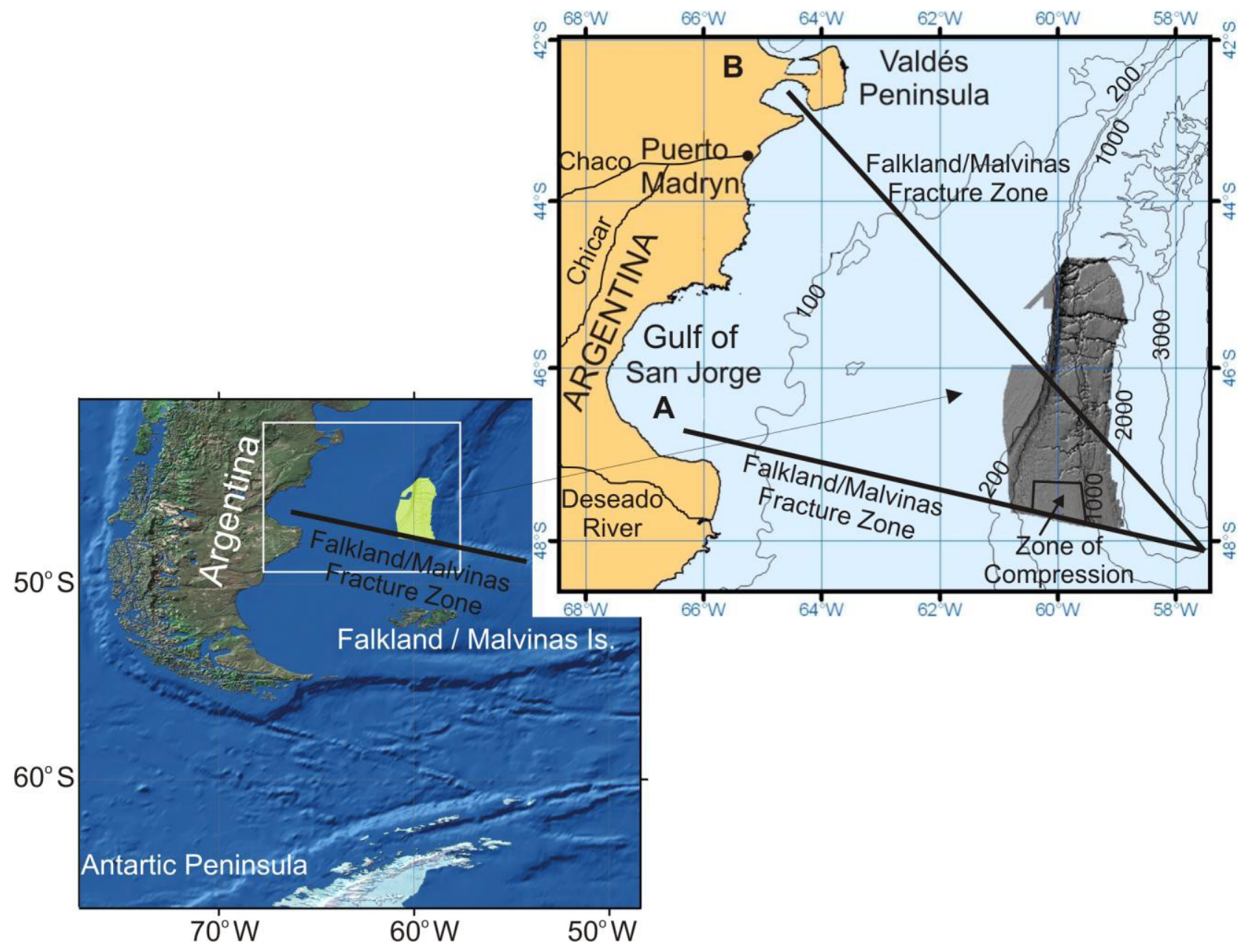

Figure 1 

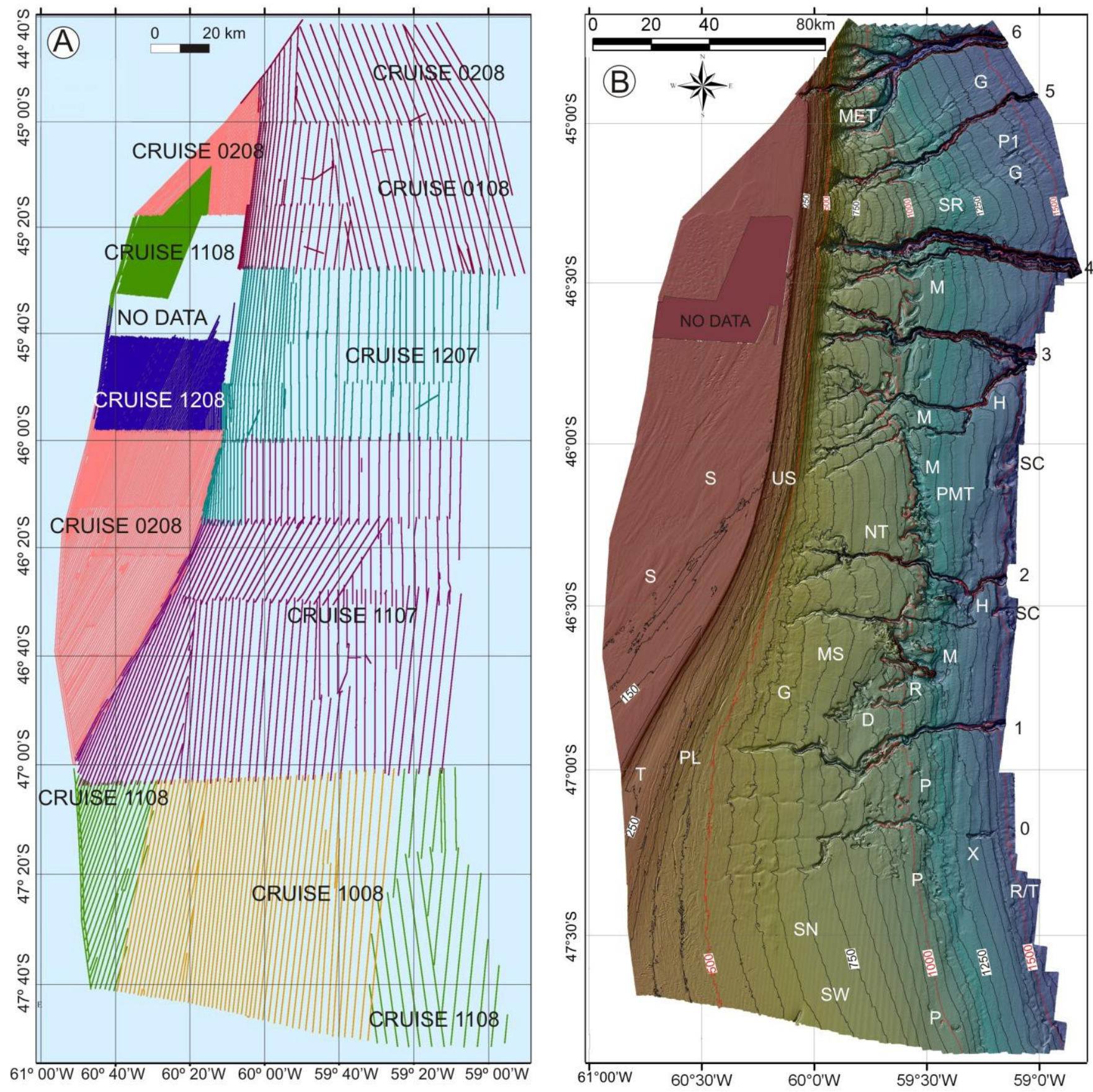

Figure 2 


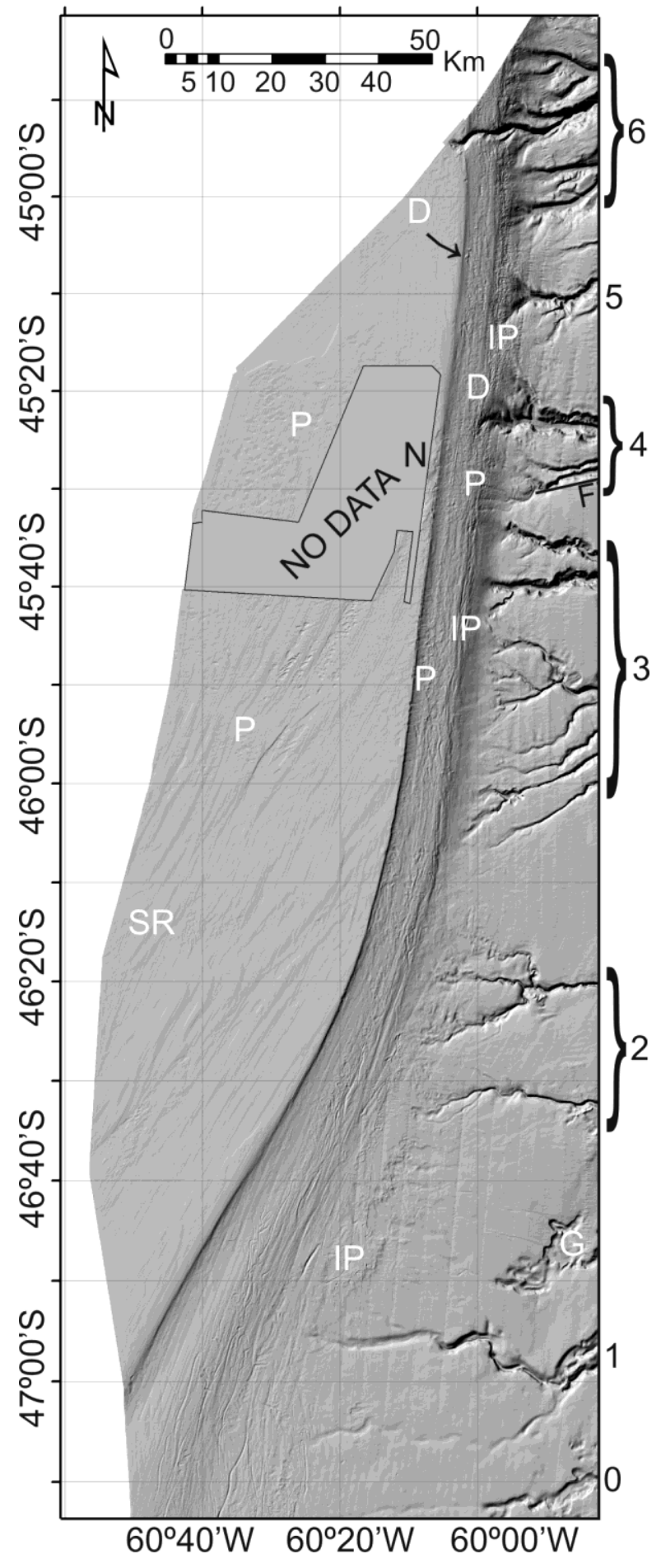

Figure 3 
(A)
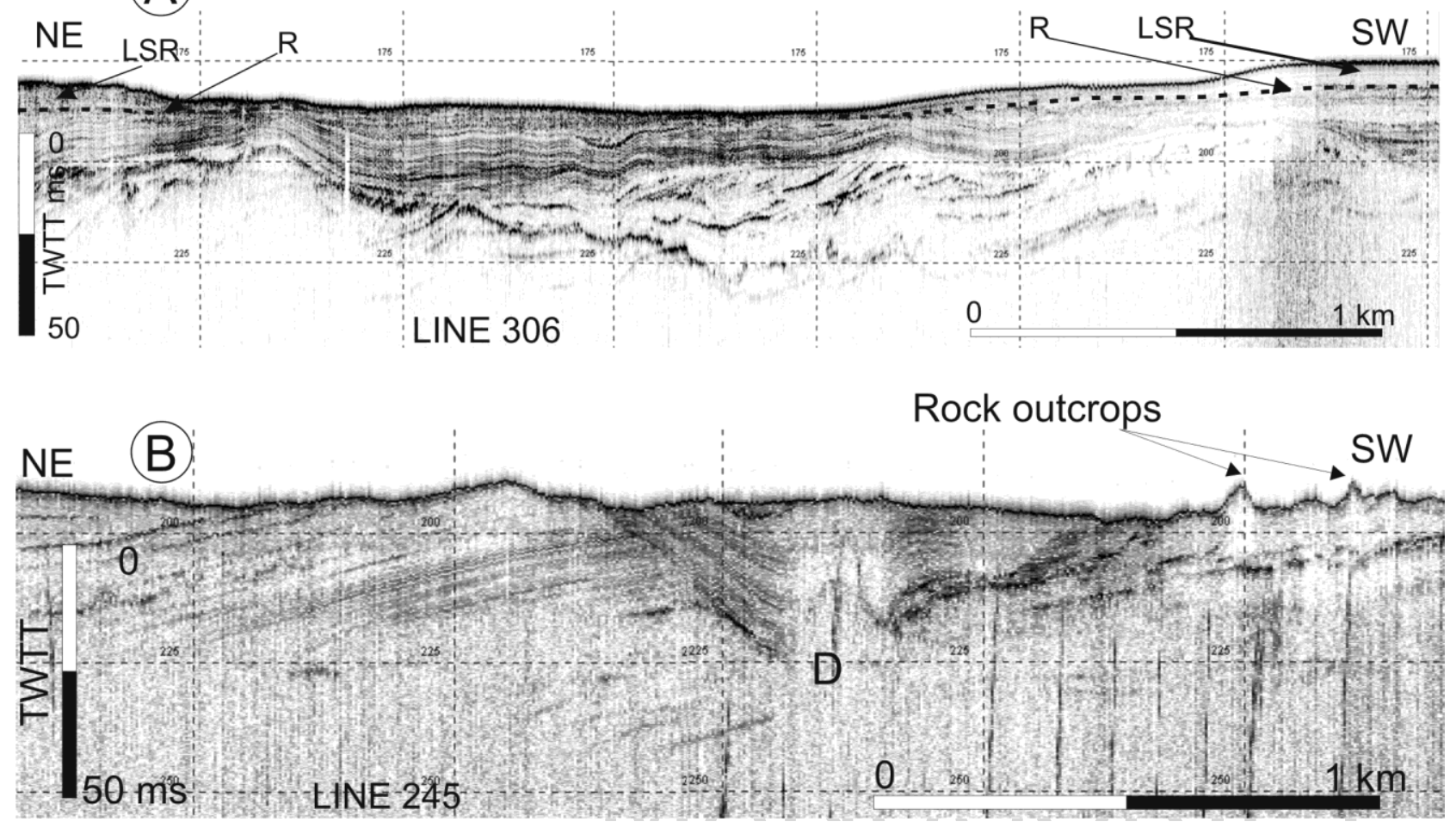

Figure 4 


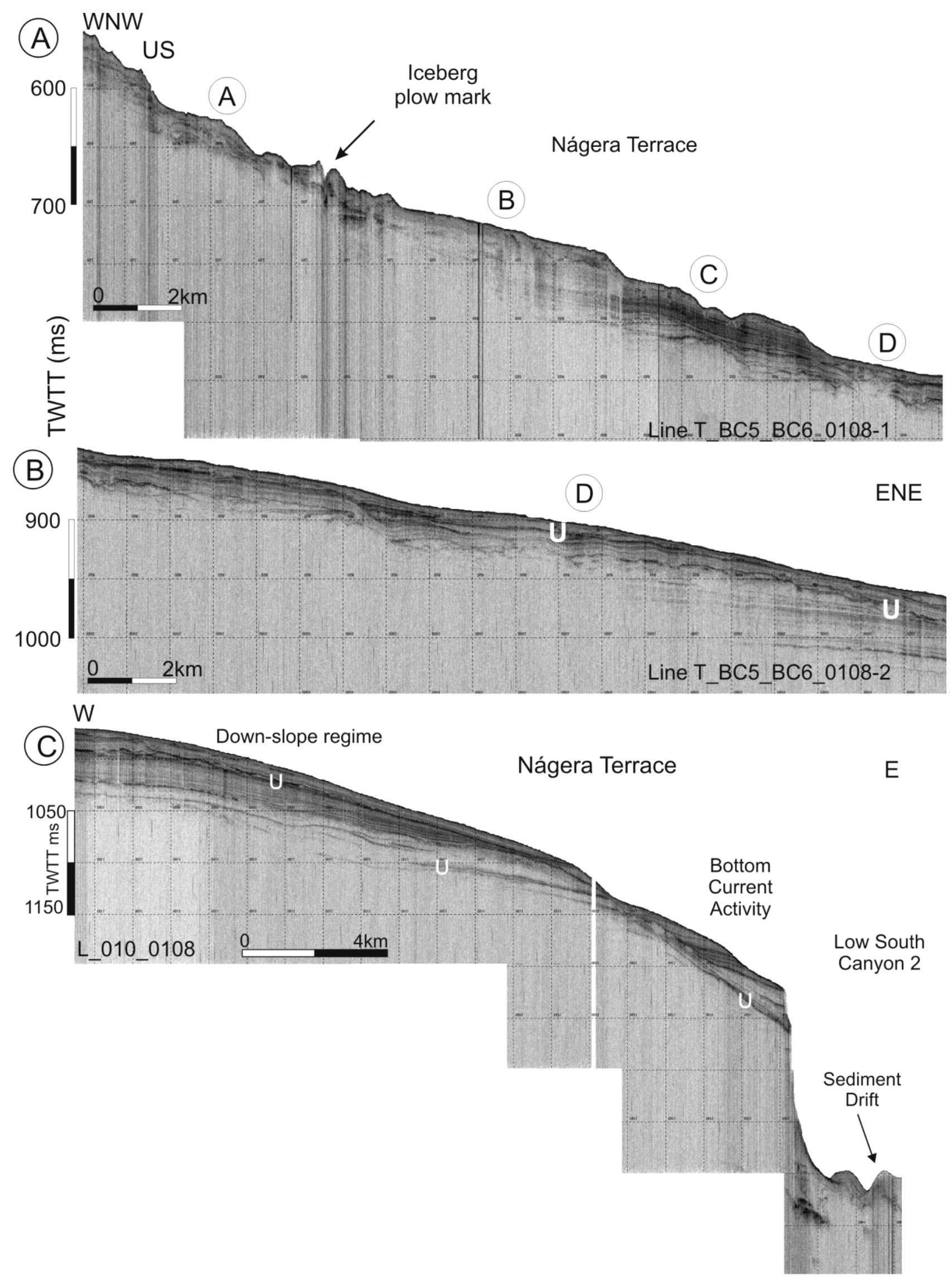

Figure 5 


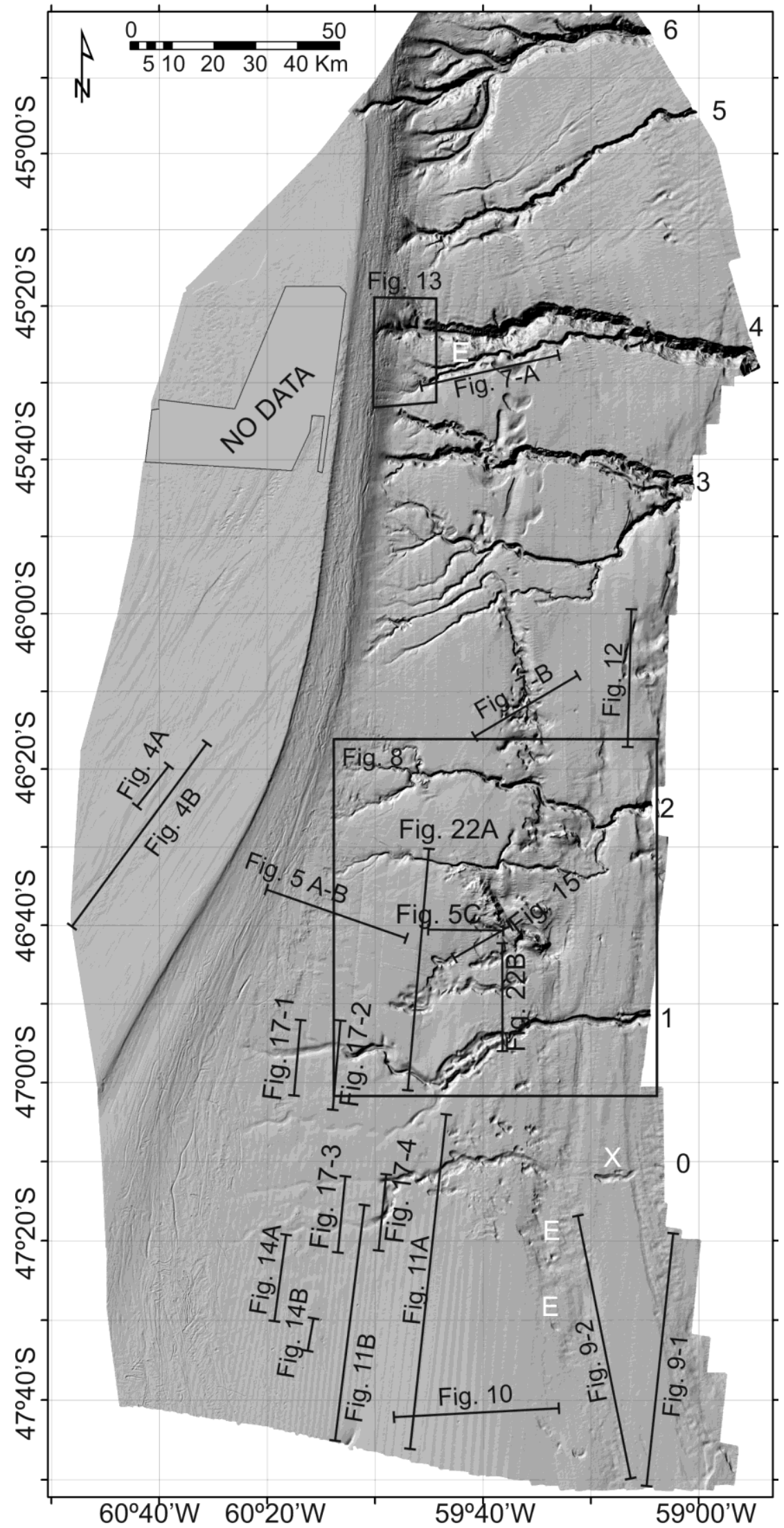

Figure 6 


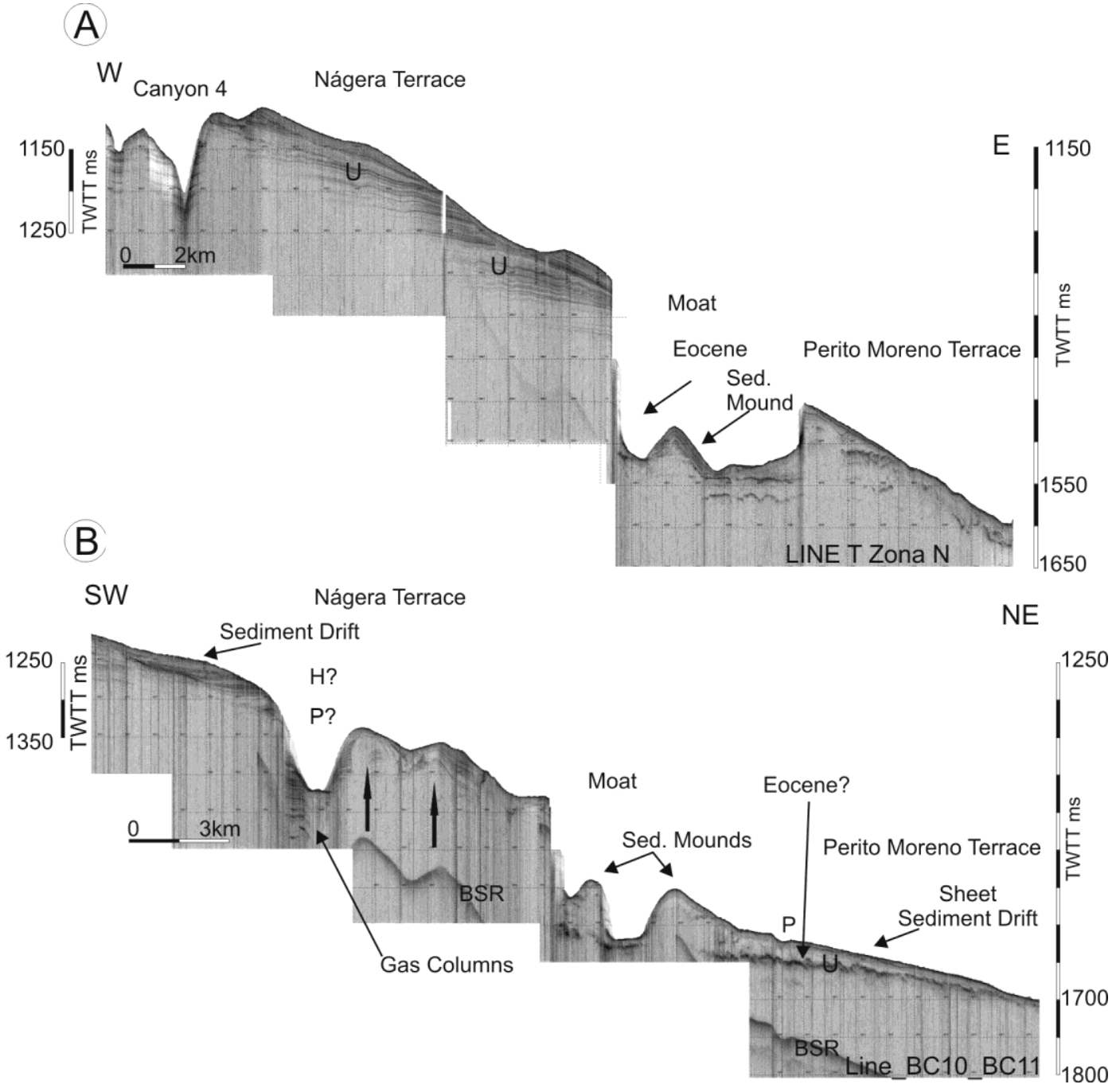

Figure 7 

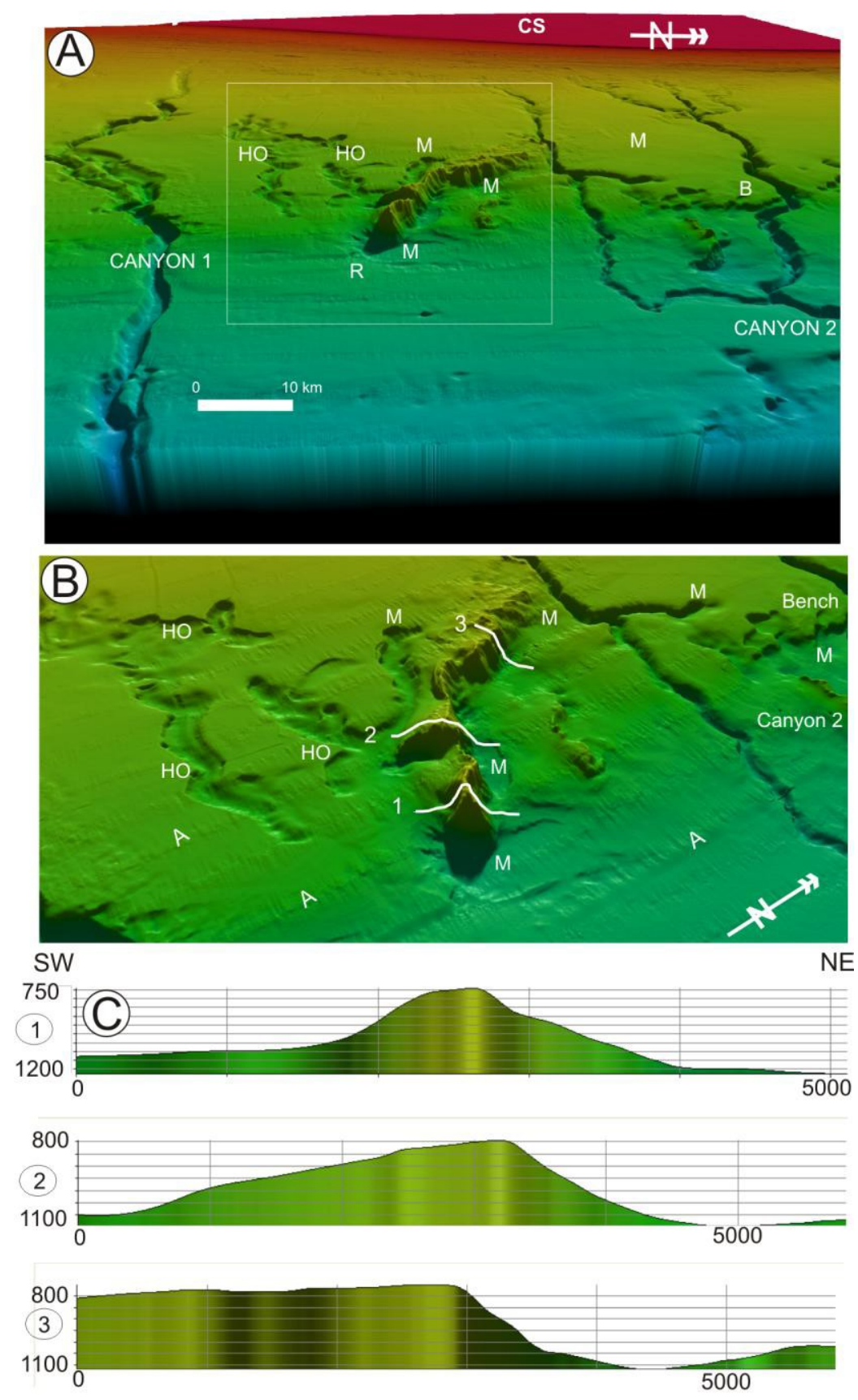

Figure 8 


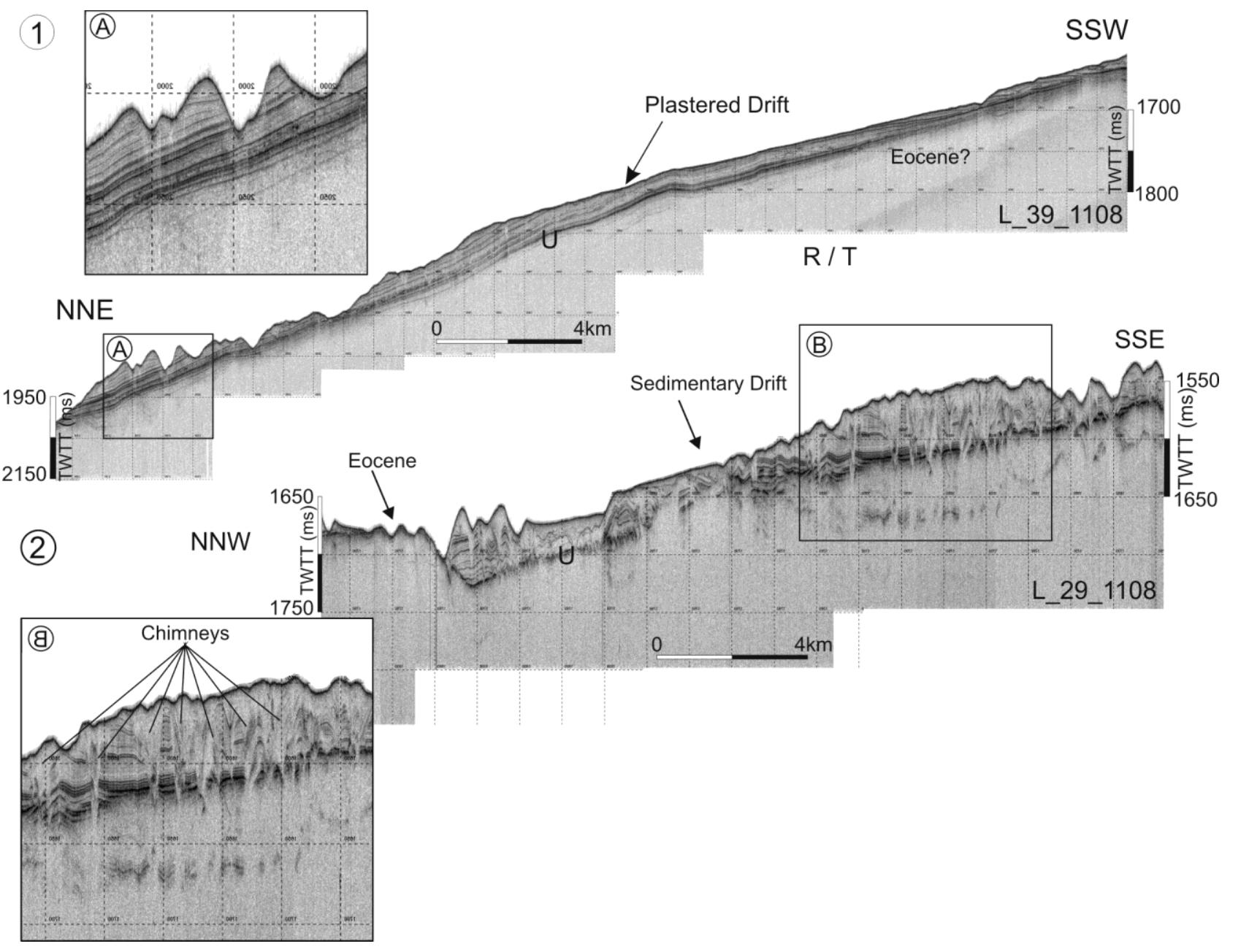

Figure 9 


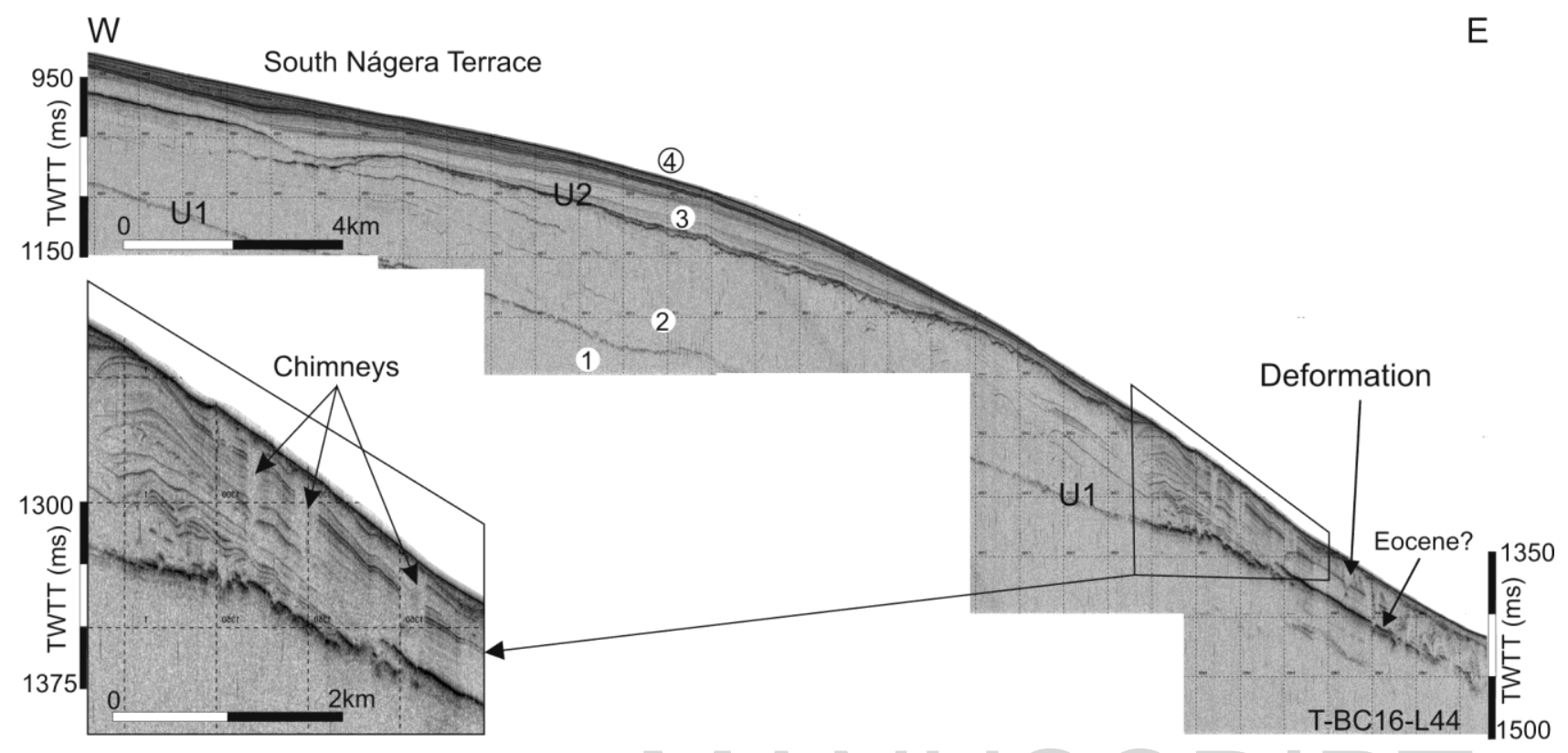

Figure 10 

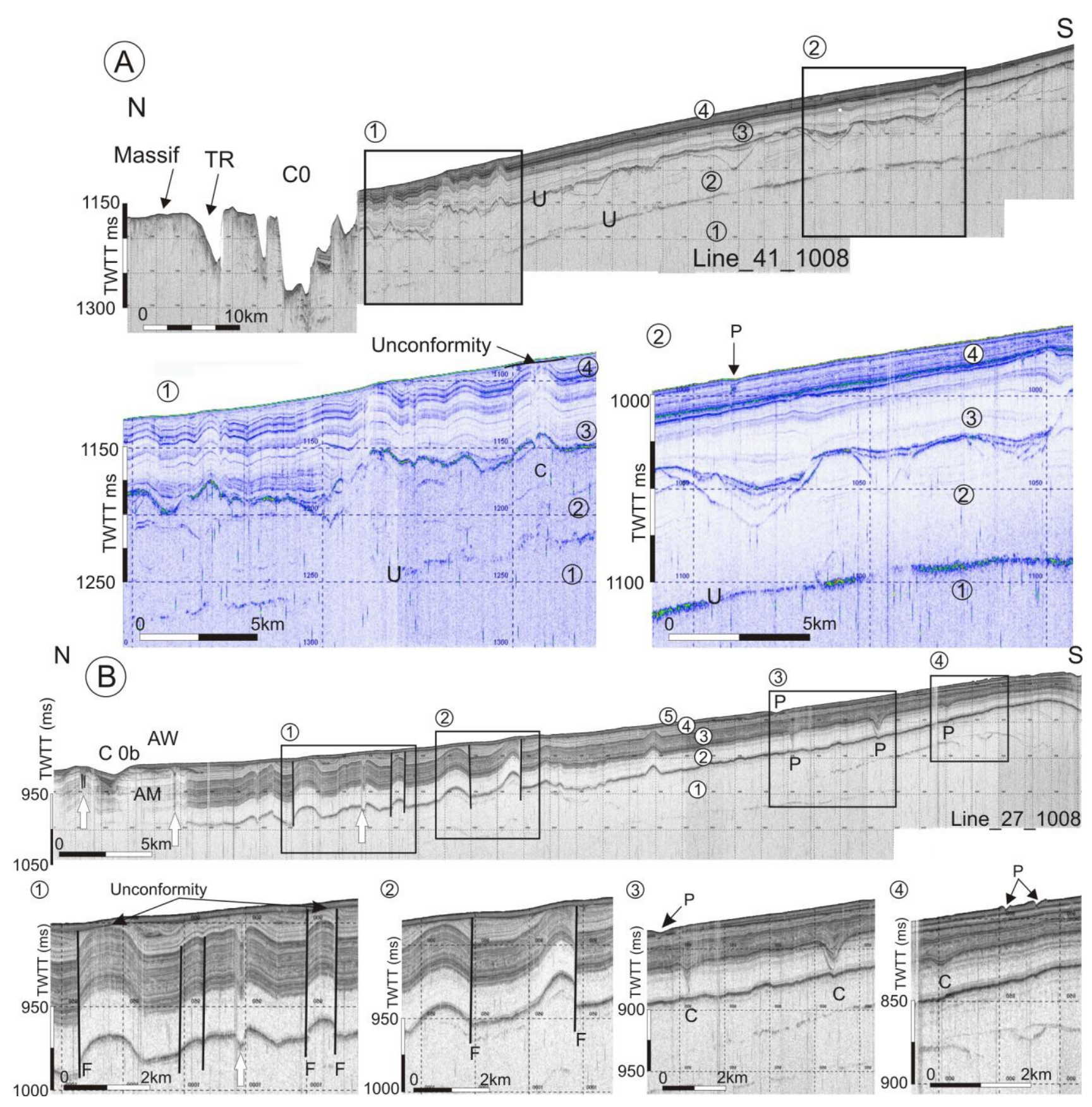

Figure 11 


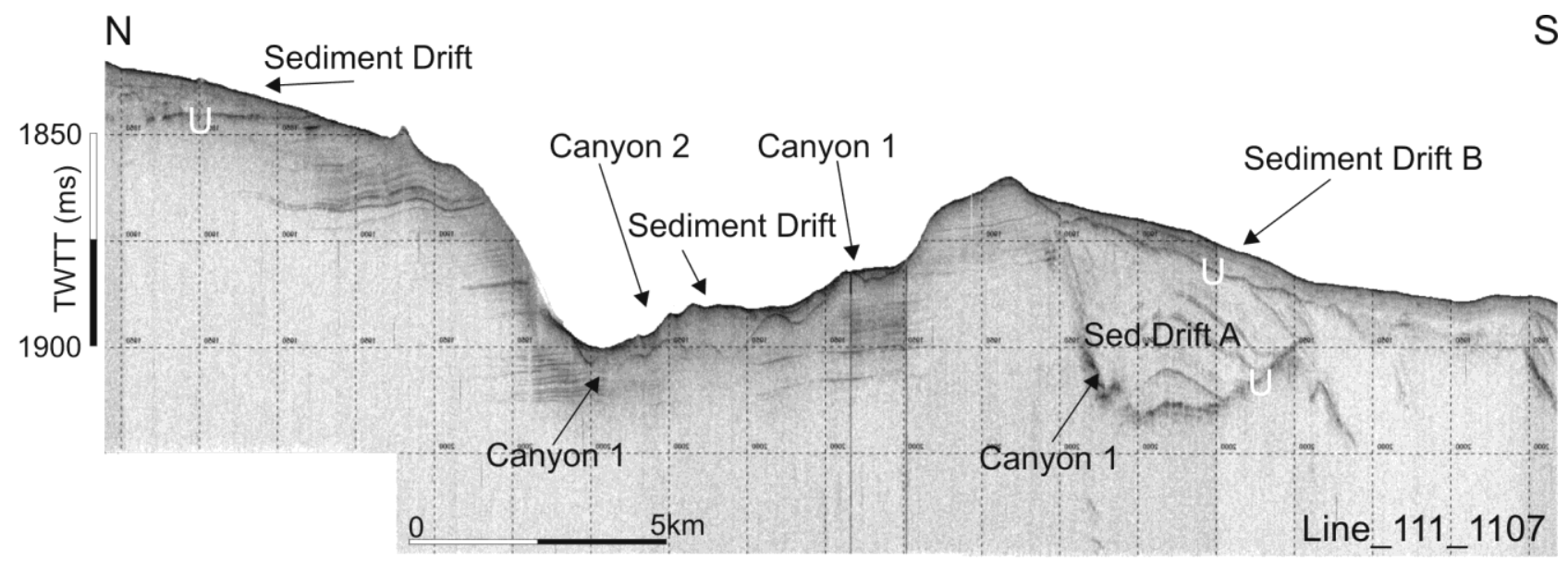

Figure 12 


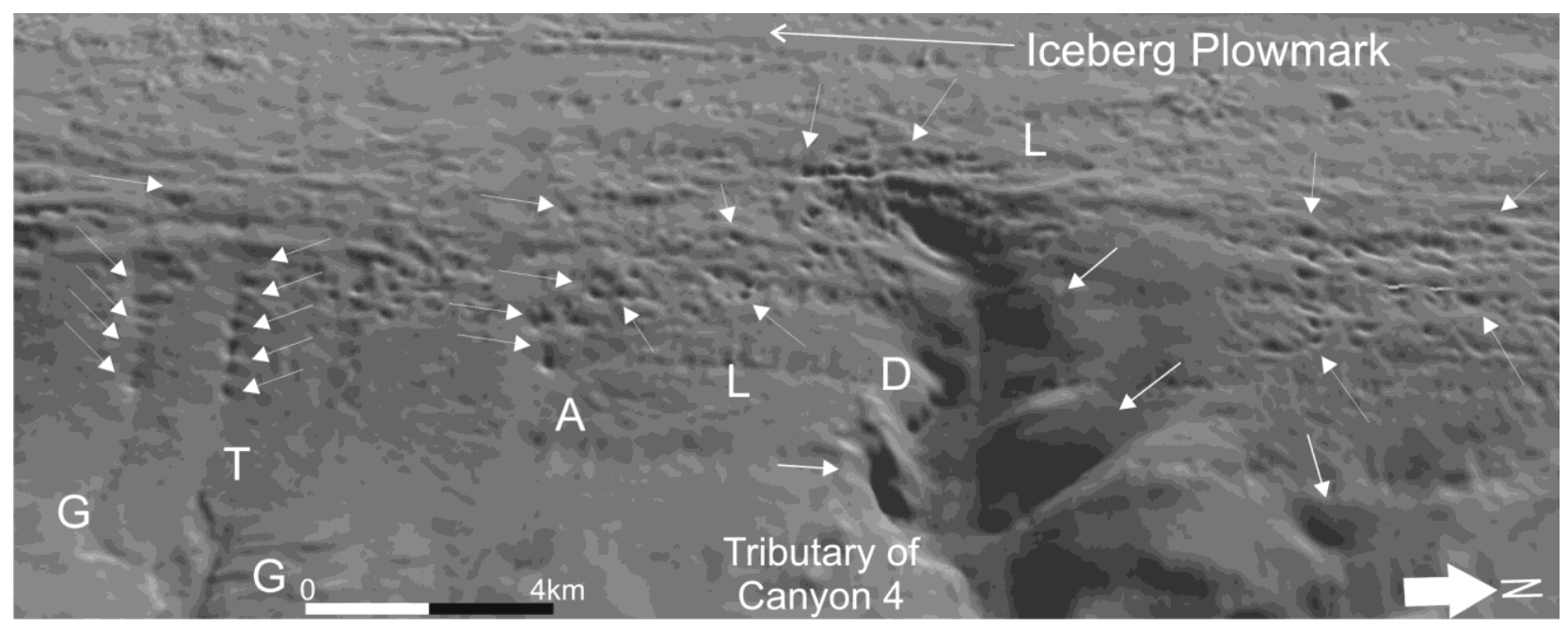

Figure 13 

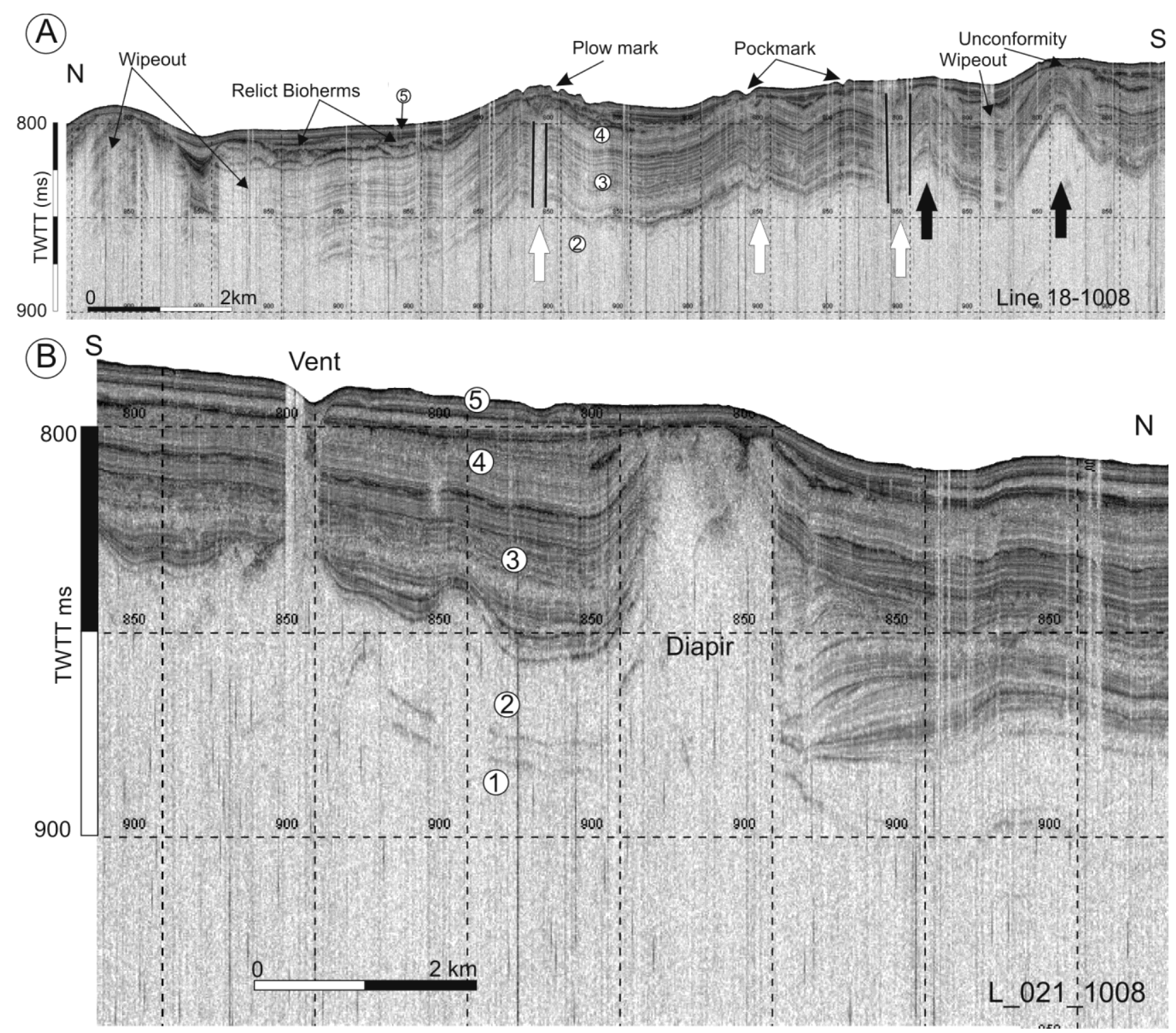

Figure 14 

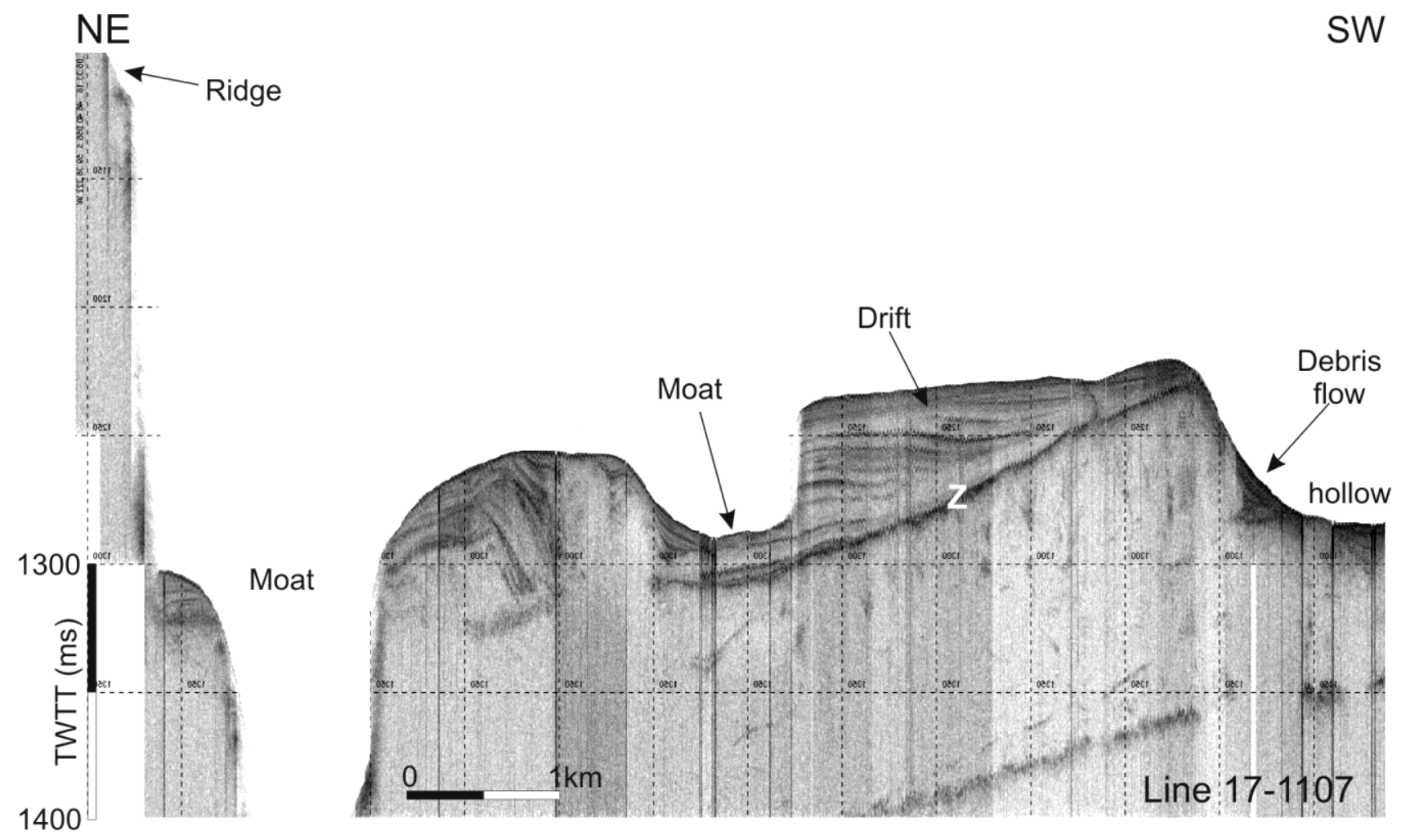

Figure 15 

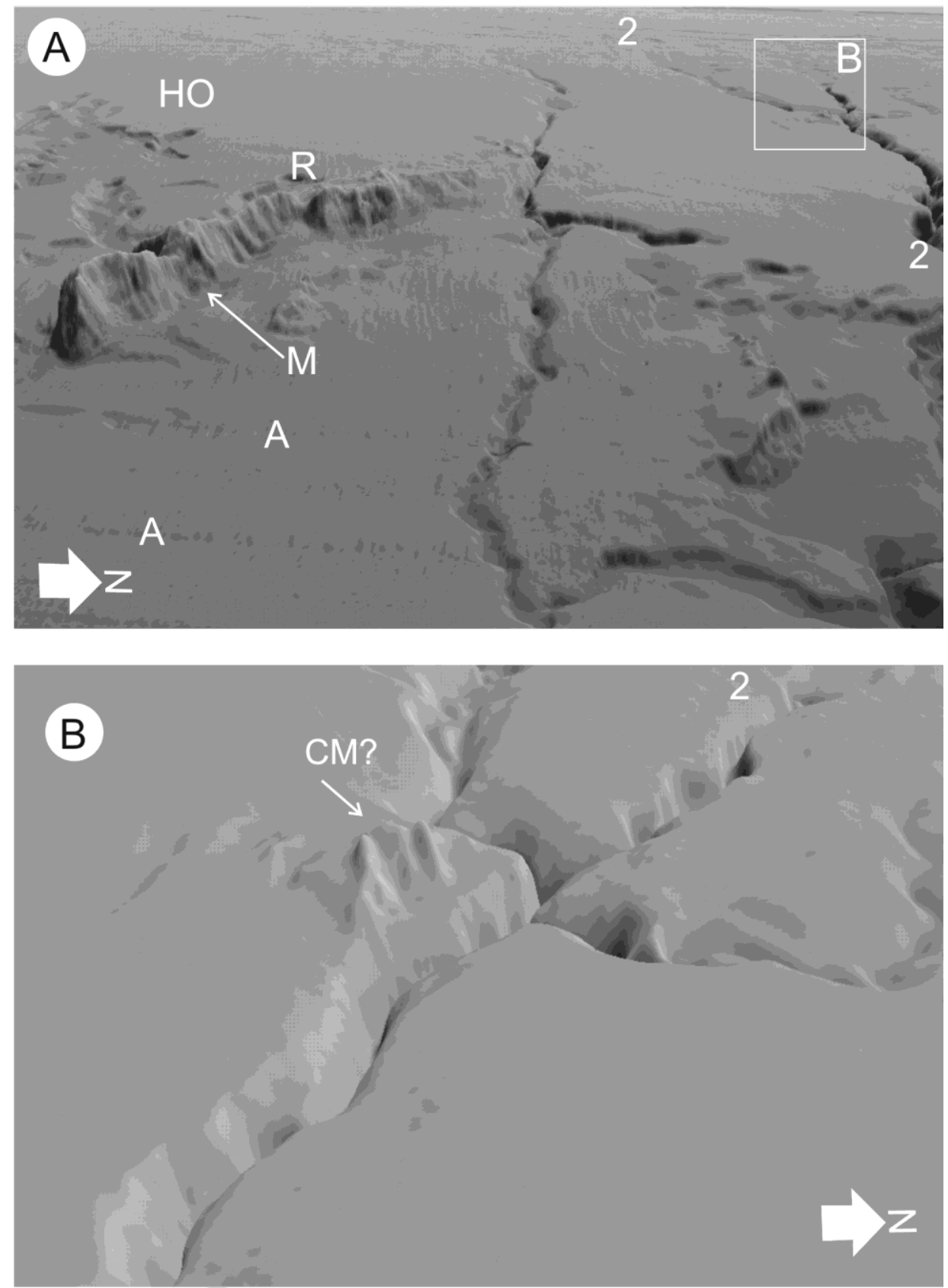

Figure 16 

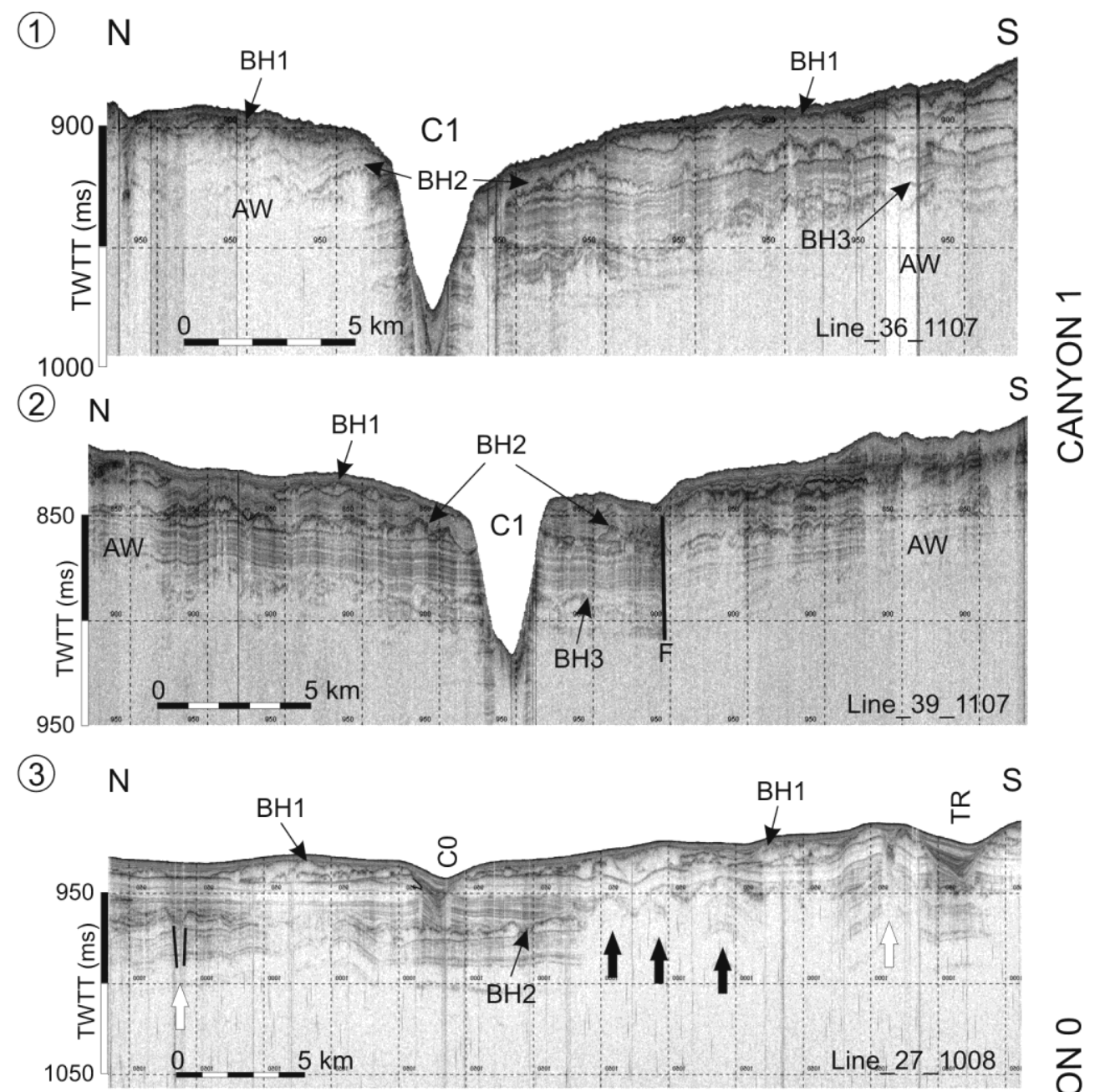

(4) $\mathrm{N}$

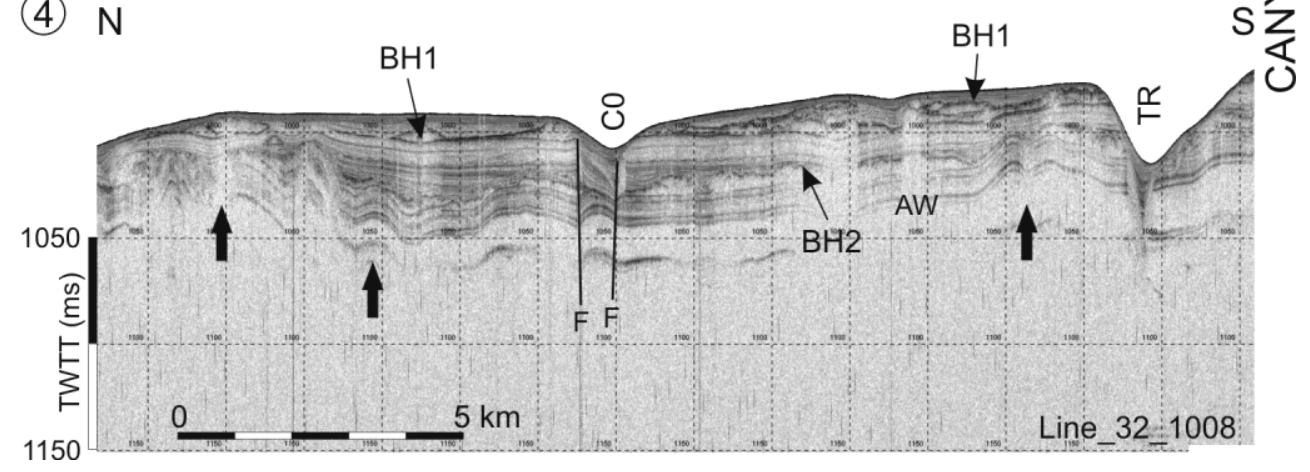

Figure 17 


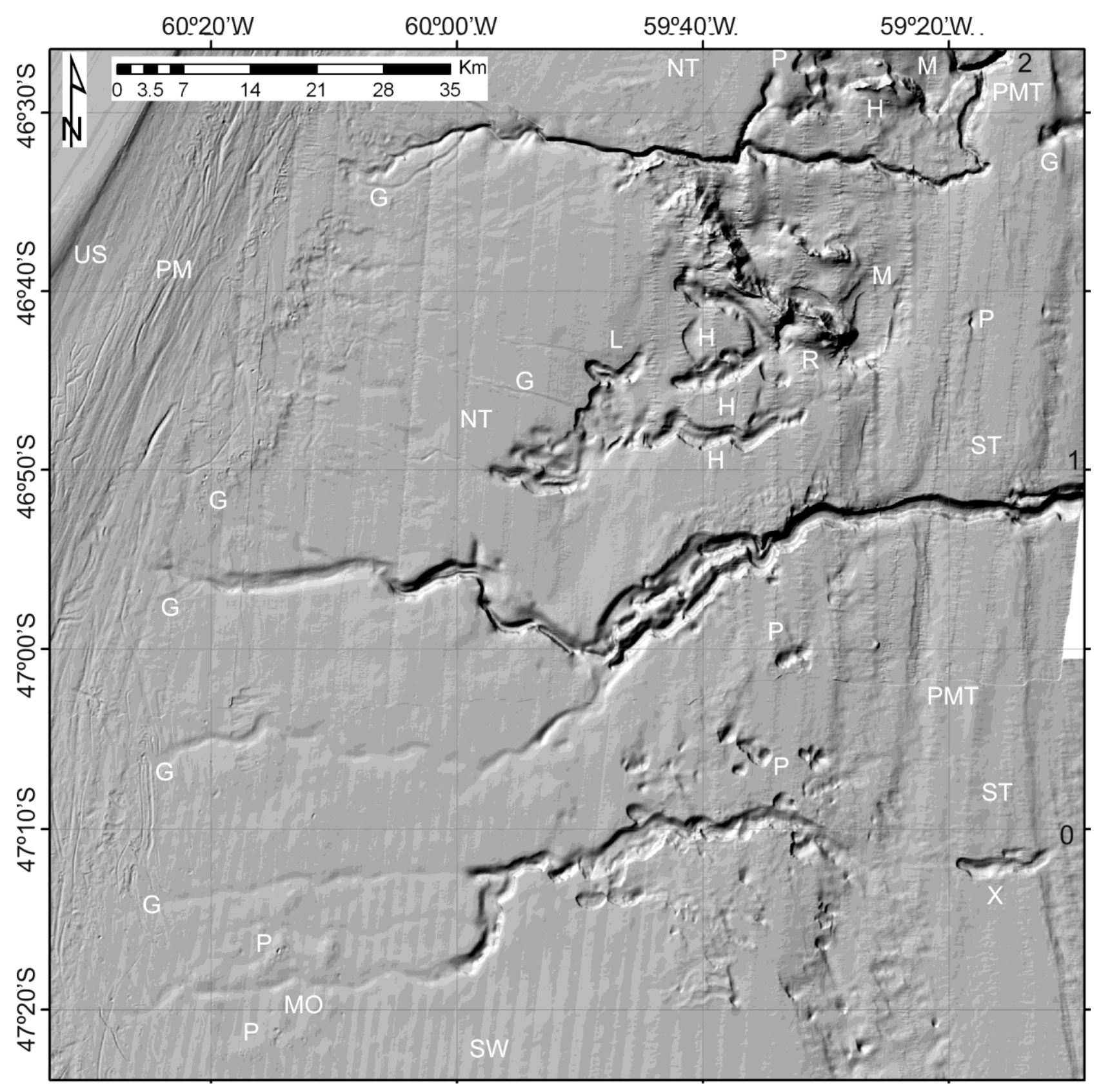

Figure 18 


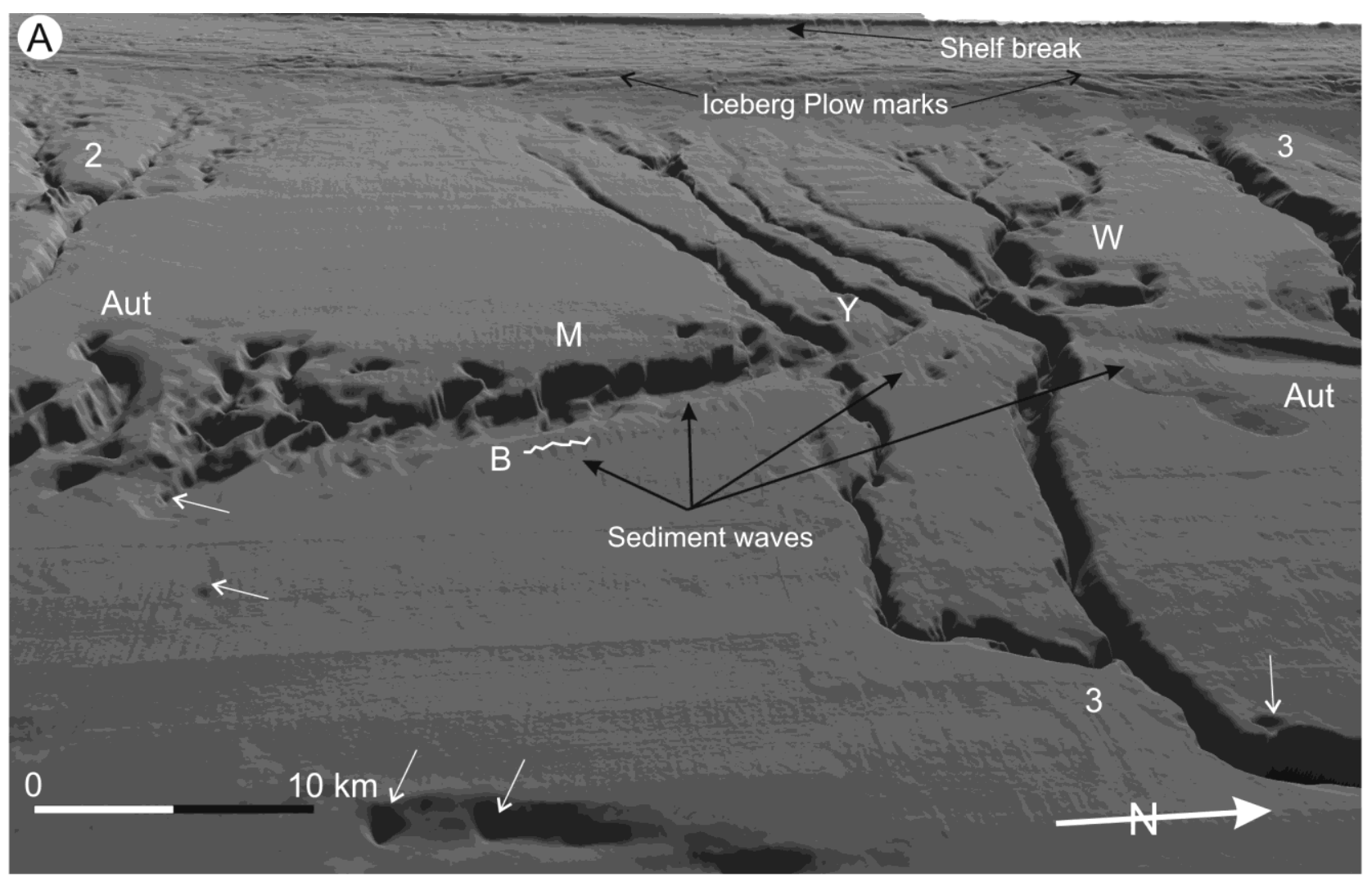

(B)

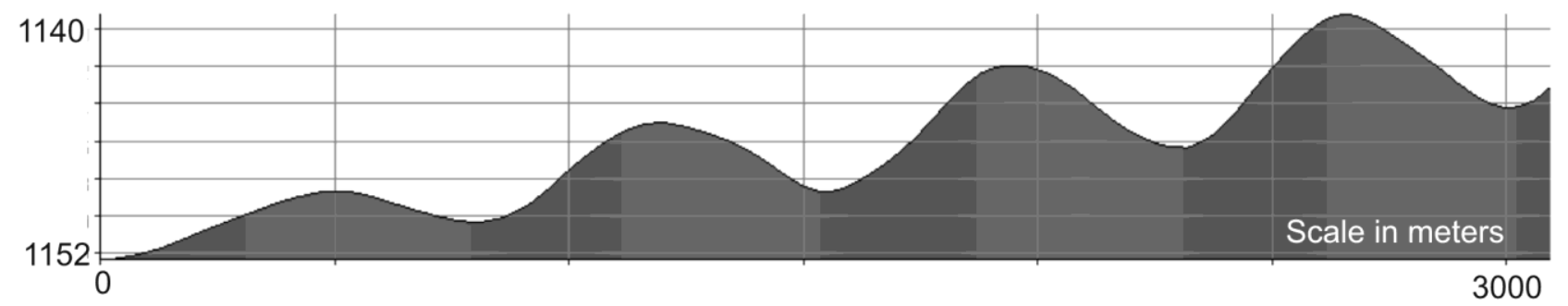

Figure 19 


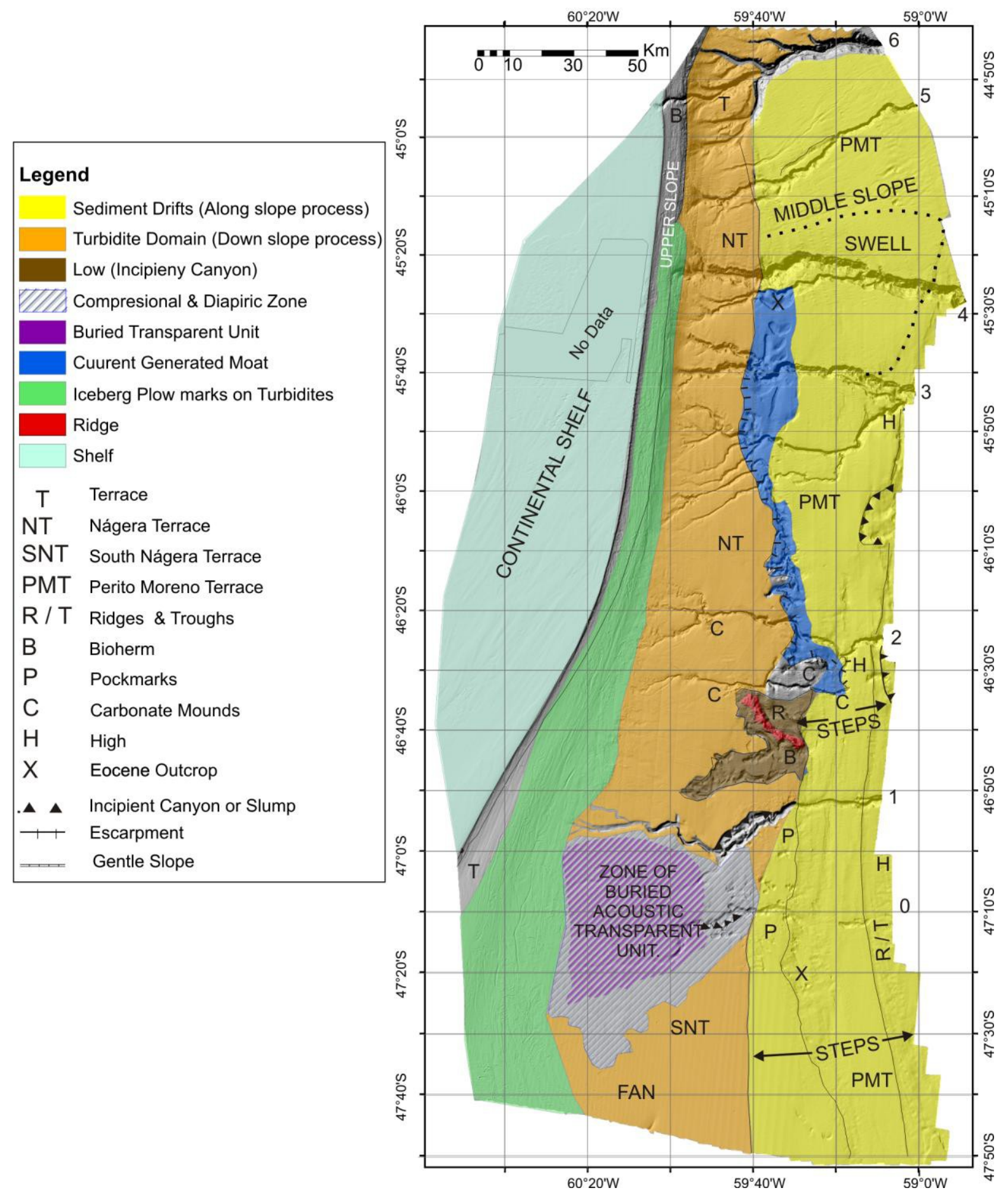

Figure 20 

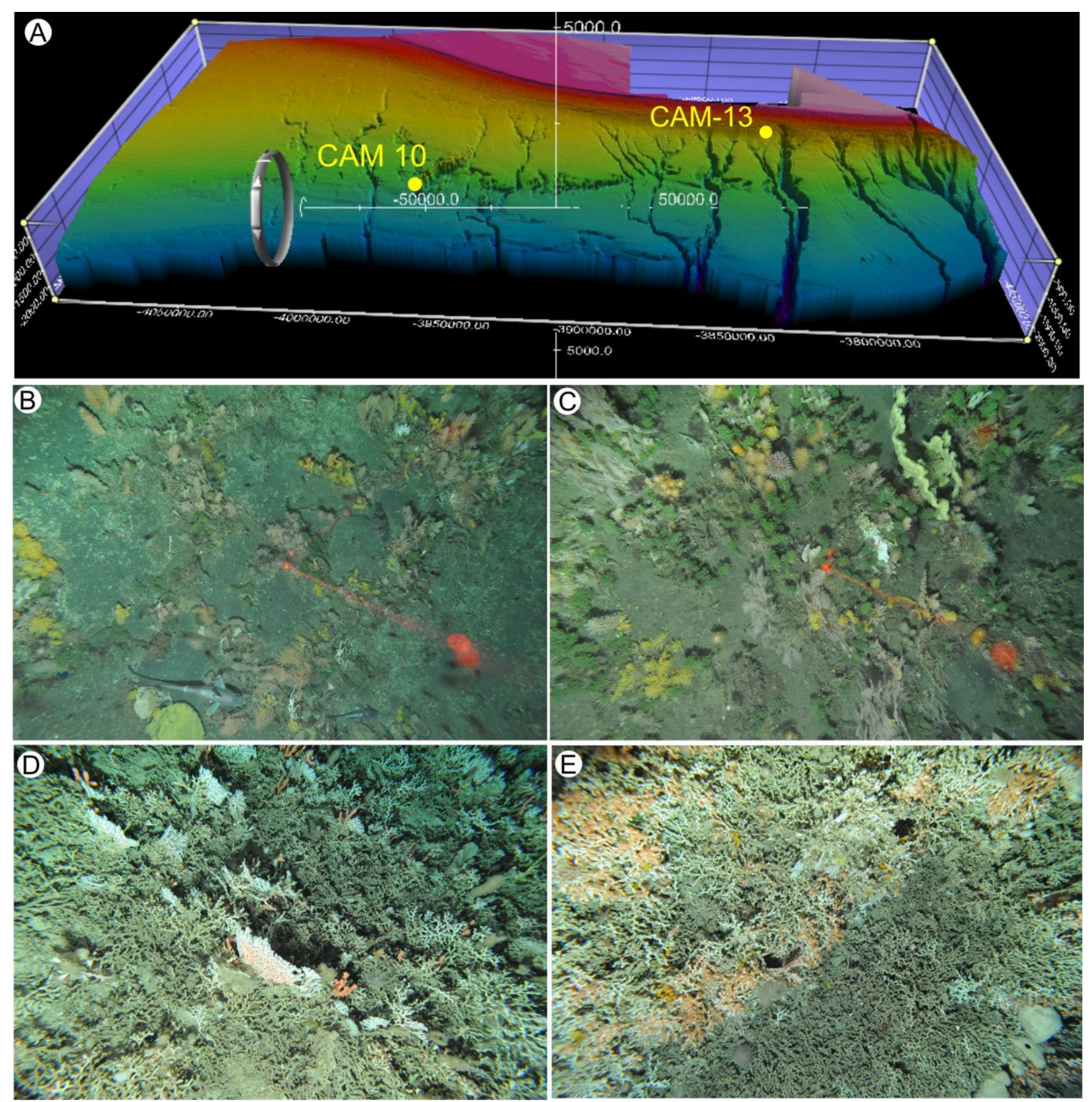

Figure 21 


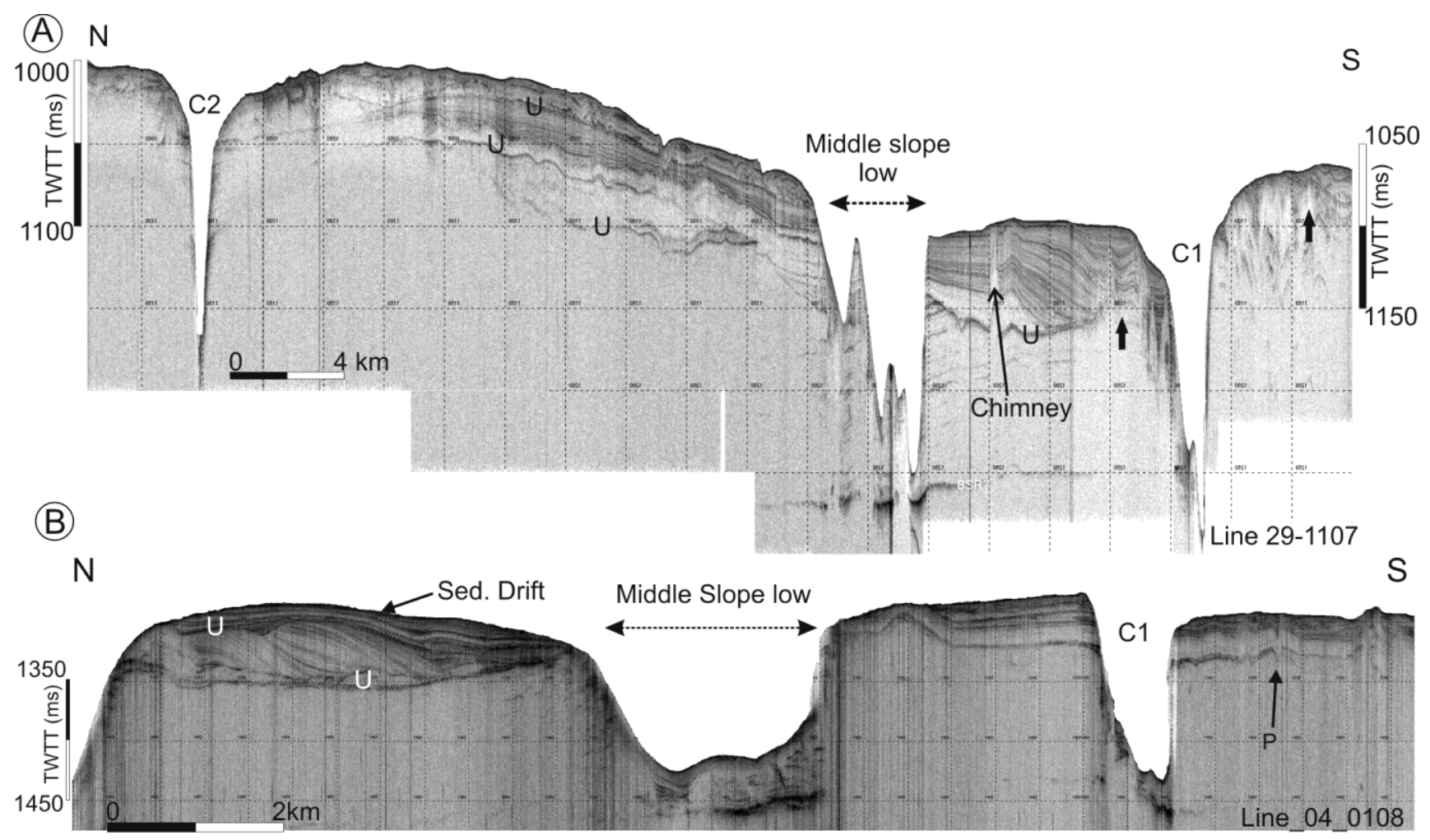

Figure 22 